NBER WORKING PAPER SERIES

\title{
THE OVERVALUATION OF RENMINBI UNDERVALUATION
}

\author{
Yin-Wong Cheung \\ Menzie D. Chinn
}

Eiji Fujii

Working Paper 12850

http://www.nber.org/papers/w12850

\author{
NATIONAL BUREAU OF ECONOMIC RESEARCH \\ 1050 Massachusetts Avenue \\ Cambridge, MA 02138 \\ January 2007
}

An earlier version of the paper was circulated under the title "Why the Renminbi Might Be Overvalued (But Probably Isn't)." We thank the discussant Barry Eichengreen, Michael Klein (whose suggestion inspired the title), Hoyt Bleakley, Joshua Aizenman, Henning Bohn, Robert Dekle, Mick Devereux, Michael Dooley, Sebastian Edwards, Michael Frommel, Reuven Glick, Linda Goldberg, Galina Hale, Koichi Hamada, Randall Henning, Owen Humpage, Gary Jefferson, Michael Klein, Akira Kohsaka, Inpyo Lee, Jaewoo Lee, Ron McKinnon, Eiji Ogawa, Brian Pinto, Eswar Prasad, Aris Protopapadakis, Andy Rose, Margot Schuller, Ulrich Volz, Shang-Jin Wei, Tom Willett, and participants at the JIMF-SCCIE conference, as well as conferences at the Federal Reserve Bank of San Francisco, the Hamburg Institute of International Economics, the ACEAS and CEANA/ASSA panels at the ASSA 2006 Meetings, the conference "WTO, China, and the Asian Economy," and the HKEA Biannual Conference for their helpful comments on the current and earlier versions of this paper. Dickson Tam, Jian Wang and Noriko Inakura provided excellent assistance in collecting data. Financial support of faculty research funds of the University of California at Santa Cruz, the University of Wisconsin, the Japan Center for Economic Research grant, and the Nomura Foundation for Social Science research grant is gratefully acknowledged. The views expressed herein are those of the authors and do not necessarily reflect the views of the National Bureau of Economic Research.

(C) 2007 by Yin-Wong Cheung, Menzie D. Chinn, and Eiji Fujii. All rights reserved. Short sections of text, not to exceed two paragraphs, may be quoted without explicit permission provided that full credit, including () notice, is given to the source. 
The Overvaluation of Renminbi Undervaluation

Yin-Wong Cheung, Menzie D. Chinn, and Eiji Fujii

NBER Working Paper No. 12850

January 2007

JEL No. F3,F4

\section{ABSTRACT}

We evaluate whether the Renminbi (RMB) is misaligned, relying upon conventional statistical methods of inference. A framework built around the relationship between relative price and relative output levels is used. We find that, once sampling uncertainty and serial correlation are accounted for, there is little statistical evidence that the RMB is undervalued. The result is robust to various choices of country samples and sample periods, as well as to the inclusion of control variables.

Yin-Wong Cheung

Department of Economics

University of California

Santa Cruz, CA 95064

cheung@ucsc.edu

Menzie D. Chinn

Dept. of Economics

University of Wisconsin

1180 Observatory Drive

Madison, WI 53706

and NBER

mchinn@lafollette.wisc.edu

\author{
Eiji Fujii \\ Graduate School of Systems \\ and Information Engineering \\ University of Tsukuba \\ Tennodai 1-1-1 \\ Tsukuba, Ibaraki \\ Japan \\ efujii@sk.tsukuba.ac.jp
}




\section{Introduction}

China's currency, the Renminbi (RMB), has occupied a central role in the ongoing debate over the source of global current account imbalances. In this paper, we step back from the debates over the merits of one exchange rate regime versus another and whether a currency realignment is desirable (although our conclusions will necessarily inform the debate over what the appropriate actions might be). Rather, we focus the discussion of currency misalignment in terms of economic theory and empirics; in particular, we focus on the difficulty in measuring the "equilibrium real exchange rate" and on quantifying the uncertainty surrounding the measurement of the level of the equilibrium. In so doing, we sharpen our definition of what constitutes currency misalignment, at the cost of restricting the generality of our conclusions.

Specifically, we exploit a well-known relationship between deviations from absolute purchasing power parity and real per capita income using panel regression methods. By placing the RMB in the context of this well-known empirical relationship exhibited by a large number of developing and developed countries, over a long time horizon, this approach addresses the question of where China's real exchange rate stands relative to the "equilibrium" level. In addition to calculating the numerical magnitude of the degree of misalignment, we assess the estimates in the context of statistical uncertainty. In this respect, we extend the standard practice of considering both economic and statistical significance in coefficient estimates to the prediction aspect.

We also extend the analysis by allowing for heterogeneity across country groupings and time periods. After conducting various robustness checks, we conclude that although the point estimates indicate the RMB is undervalued in almost all samples, in almost no case is the deviation statistically significant, and indeed, when serial correlation is accounted for, the extent of misalignment is not even statistically significant at the 50\% level. These findings highlight the great degree of uncertainty surrounding empirical estimates of "equilibrium real exchange rates", thereby underscoring the difficulty in accurately assessing the degree of RMB undervaluation.

We further assess the robustness of the results in the presence of several conditioning variables. These additional factors include demographic variables, measures of trade openness, policy factors such as the extent of capital controls, and institutional 
factors. While these conditioning variables exert significant effects, their inclusion does not change the basic message: the RMB appears to be undervalued, but not by a statistically significant margin.

\section{Preliminary Discussion}

\subsection{A Brief Literature Review}

At the heart of the debate over the right way of determining the appropriate exchange rate level are contrasting ideas of what constitutes an equilibrium exchange rate, what time frame the equilibrium condition pertains to, and, not least, what econometric method to implement. ${ }^{1}$ Some short cuts have been used so often that some forget that they are short cuts.

Most of the extant studies fall into some familiar categories, either relying upon some form of relative purchasing power parity (PPP) or cost competitiveness calculation, the modeling of deviations from absolute PPP, a composite model incorporating several channels of effects (sometimes called behavioral equilibrium exchange rate models), or flow equilibrium models. ${ }^{2}$

The relative PPP comparisons are the easiest to make, in terms of numerical calculation. On the other hand, relative PPP is uninformative about how a country's exchange rate stands relative to others.

Bosworth (2004), Frankel (2005), Coudert and Couharde (2005), and Cairns (2005b) estimate the relationship between the deviation from absolute PPP and relative per capita income. All obtain similar results regarding the relationship between the two variables (although Coudert and Couharde fail to detect this link for the RMB in their time series analysis).

Zhang (2001), Wang (2004), and Funke and Rahn (2005) implement what could broadly be described as behavioral equilibrium exchange rate (BEER) specifications. ${ }^{3}$ These models incorporate a variety of channels through which the real exchange rate is affected. Since each author selects different variables to include, the implied

\footnotetext{
$1 \quad$ One relevant work is Hinkle and Montiel (1999).

2 See Table 1 of Cheung, Chinn and Fujii (forthcoming) for a typology of these different approaches.

3 Also known as BEERs, a composite of exchange rate models.
} 
misalignments will necessarily vary. In addition, these approaches will fail to identify if a currency is misaligned relative to another country's for the same reason that relative PPP fails to do so - because they typically rely upon price indices but not actual prices.

Other approaches center on flow equilibria, considering savings and investment behavior and the resulting implied current account. The equilibrium exchange rate is derived from the implied medium term current account using import and export elasticities. In the IMF's "macroeconomic approach", the "norms" are estimated, in the spirit of Chinn and Prasad (2003). Wang (2004) discusses the difficulties in using this approach for China but does not present estimates of misalignment based upon this framework. Coudert and Couharde (2005) implement a similar approach. Finally, the external balances approach relies upon assessments of the persistent components of the balance of payments condition (Goldstein, 2004; Bosworth, 2004). This last set of approaches is perhaps most useful for conducting short-term analyses. But the wide dispersion in implied misalignments reflects the difficulties in making judgments about what constitutes persistent capital flows. For instance, Prasad and Wei (2005), examining the composition of capital inflows into and out of China, argue that much of the reserve accumulation that has occurred in recent years is due to speculative inflows; hence, the degree of misalignment is small. ${ }^{4}$

In his survey, Cairns (2005a) observes that studies implementing an absolute PPP methodology result in the greatest degree of estimated undervaluation. Those implementing either relative PPP or flow equilibrium approaches find smaller estimates of undervaluation. ${ }^{5}$

\subsection{Bilateral and Effective Exchange Rate Indexes}

To highlight the drawbacks of this oft-used relative PPP approach, we examine briefly what this methodology says about the RMB. Figure 1 depicts the official exchange rate series from January 1987 to May 2006, deflated by the US and Chinese

\footnotetext{
$4 \quad$ Moreover, such judgments based upon flow criteria must condition their conclusions on the existence of effective capital controls. This is an obvious - and widely acknowledged - point, but one that bears repeating and, indeed, is a point that we will return to at the end of this paper.

5 Dunaway and Li (2005) made a similar observation.
} 
CPI's. The rate is expressed so higher values mean a stronger Chinese currency (the units of currency are denoted as CNY, for Chinese Yuan). In line with expectations, in the years since the East Asian crisis, the RMB has experienced a downward decline in value.

However, as with the case with many economies experiencing transitions from controlled to partially decontrolled capital accounts and from dual to unified exchange rate regimes, there is some dispute over what exchange rate measure to use. It turns out that in the years leading up to 1994, increasingly large amounts of RMB transactions were taking place at "swap rates" - rather than the official rate - so that the 1994 "megadevaluation" is actually better described as a unification of different rates of exchange (Fernald, Edison, and Loungani, 1999). The "adjusted" rate in Figure 1 is a weighted average of the official and the swap rates.

In the early warning system literature that developed in the wake of the financial crises of the 1990's, a typical measure of currency misalignment was the deviation from a deterministic trend. Using the "adjusted" rate, and fitting a linear time trend, one finds a modest undervaluation in the May of 2006 of $1.3 \%$, contrasting slightly with the 5\% overvaluation implied by the official exchange rate.

In general, trade weighted exchange rates provide better measures of relative prices. However, using this same methodology on this exchange rate does not necessarily clarify matters. ${ }^{6}$ Figure 2 depicts the IMF's trade weighted effective exchange rate index, and a fitted linear. One finds that focusing on the deviations from a simple trend indicates the RMB is $30 \%$ overvalued. Of course, a quick glance at the data indicates that a simple trend is much too simplistic a characterization. Suppose instead that one assumed that the relevant period was 1987 onward; then a flat trend and zero misalignment would be the determination. The fact that working with simple straight line extrapolations can lead to such diverging conclusions suggests that we need to take a closer look at where the Chinese currency should stand, both over time and across countries.

\section{Absolute Purchasing Power Parity}

$6 \quad$ As a matter of principal, trade weighted rates are to be preferred to bilateral rates since the reliance on the latter can lead to misleading inferences about overall competitiveness. 


\subsection{The Real Exchange Rate - Income Relationship}

As a first cut, we appeal to a simple, and apparently robust, relationship between the real exchange rate and per capita income. We will then elaborate the analysis by stratifying the data along other dimensions (level of development, time period), and by adding in other variables that might alter one's assessment of the fundamental equilibrium level of the exchange rate.

First, let us consider the basic framework of analysis. Consider the law of one price, which states that the price of a single good should be equalized in common currency terms (expressed in logs):

$$
p_{i, t}=s_{t}+p_{i, t}^{*}
$$

where $s_{t}$ is the $\log$ exchange rate, $p_{i, t}$ is the $\log$ price of good $i$ at time $t$, and the asterisk denotes the foreign country variable. Summing over all goods, and assuming the weights associated with each good are the same in both the home country and foreign country basket, one then obtains the absolute purchasing power parity condition:

$$
p_{t}=s_{t}+p_{t}^{*}
$$

where for simplicity assume $p$ is a arithmetic average of individual log prices. As is well known, if the weights differ between home and foreign country baskets (let's say production bundles), then even if the law of one price holds, absolute purchasing power parity need not hold.

The "price level" variable in the Penn World Tables (Summers and Heston, 1991), and other purchasing power parity exchange rates, attempt to circumvent this problem by using prices (not price indices) of goods, and calculating the aggregate price level using the same weights. Assume for the moment that this can be accomplished, but that some share of the basket $(\alpha)$ is nontradable (denoted by N subscript), and the remainder is tradable (denoted by $\mathrm{T}$ subscript). Then:

$$
p_{t}=\alpha p_{N, t}+(1-\alpha) p_{T, t}
$$

By simple manipulation, one finds that the "real exchange rate" is given by:

$$
q_{t} \equiv s_{t}-p_{t}+p_{t}^{*}=\left(s_{t}-p_{T, t}+p_{T, t}^{*}\right)-\alpha\left[p_{N, t}-p_{T, t}\right]+\alpha\left[p_{N, t}^{*}-p_{T, t}^{*}\right]
$$


Rewriting, and indicating the first term in (parentheses), the intercountry price of tradables, as $q_{T, t}$ and the intercountry relative price of nontradables as $\omega_{t} \equiv$ $\left[p_{N, t}-p_{T, t}\right]-\left[p_{N, t}^{*}-p_{T, t}^{*}\right]$, leads to the following rewriting of (4):

$$
q_{t}=q_{T, t}-\alpha \omega_{t}
$$

This expression indicates that the real exchange rate can appreciate as changes occur in the relative price of traded goods between countries, or as the relative price of nontradables rises in one country, relative to another. In principle, economic factors can affect one or both.

Most models of the real exchange rate can be categorized according to which specific relative price serves as the object of focus. If the relative price of nontradables is key, then the resulting models - in a small country context - have been termed "dependent economy" (Salter, 1959, and Swan, 1960) or "Scandinavian" model. In the former case, demand side factors drive shifts in the relative price of nontradables. In the latter, productivity levels and the nominal exchange rate determine the nominal wage rate, and hence the price level and the relative price of nontradables. In this latter context, the real exchange rate is a function of productivity (Krueger, 1983: 157). Consequently, the two sets of models both focus on the relative nontradables price, but differ in their focus on the source of shifts in this relative price. Since the home economy is small relative to the world economy (hence, one is working with a one-country model), the tradable price is pinned down by the rest-of-the-world supply of traded goods. Hence, the "real exchange rate" in this case is $\left(p^{N}-p^{T}\right)$.

By far dominant in this category are those that center on the relative price of nontradables. These include the specifications based on the approaches of Balassa (1964) and Samuelson (1964) that model the relative price of nontradables as a function of sectoral productivity differentials, including Hsieh (1982), Canzoneri, Cumby and Diba (1999), and Chinn (2000a). They also include those approaches that include demand side determinants of the relative price, such as that of DeGregorio and Wolf (1994). They observe that if consumption preferences are not homothetic and factors are not perfectly free to move intersectorally, changes in per capita income may result shifts in the relative price of nontradables. 
This perspective provides the key rationale for the well-known positive crosssectional relationship between relative price (the inverse of $q$, i.e., $-q$ ) and relative per capita income levels. We exploit this relationship to determine whether the Chinese currency is undervalued. Obviously, this approach is not novel; it has been implemented recently by Coudert and Couharde (2005) and Frankel (2006). However, we will expand this approach along several dimensions. First, we augment the approach by incorporating the time series dimension. ${ }^{7}$ Second, we explicitly characterize the uncertainty surrounding our determinations of currency misalignment. Third, we examine the stability of the relative price and relative per capita income relationship using a) subsamples of certain country groups and time periods, and b) control variables.

Before proceeding further, it is important to be explicit about the type of equilibrium we are associating with our measure of the "normal" exchange rate level. Theoretically, the equilibrium exchange rate in the Balassa-Samuelson approach is the one that is consistent with both internal and external balances. In reality, however, internal and external balance is not guaranteed. Thus, the estimated exchange rate measure is properly interpreted as a long-run measure and is ill-suited (on its own) to analyzing short run phenomena. As a remedy, we include control variables that are relevant for (short-run) variations in internal and external balances in the subsequent analyses. $^{8}$

\subsection{The Basic Bivariate Results}

We compile a large data set encompassing up to 160 countries over the 19752004 period. Most of the data are drawn from the World Bank's World Development Indicators (WDI). Because some data are missing, the panel is unbalanced. Appendix 1 gives a greater detail on the data used in this subsection and elsewhere.

\footnotetext{
$7 \quad$ Coudert and Couharde (2005) implement the absolute PPP regression on a crosssection, while their panel estimation relies upon estimating the relationship between the relative price level to relative tradables to nontradables price indices.

$8 \quad$ Frankel (2006) discusses whether one can speak of an "equilibrium exchange rate" when there is more than one sector to consider.
} 
Extending Frankel's (2006) cross-section approach, we estimate the real exchange rate-income relationship using a pooled time-series cross-section (OLS) regression, where all variables are expressed in terms relative to the US;

$$
q_{i t}=\beta_{0}+\beta_{1} y_{i t}+u_{i t},
$$

where $q$ is expressed in real terms relative to the US price level, $y$ is real per capita income also relative to the US. ${ }^{9}$ The results are reported in the first two columns of Table 1 , for cases in which we measure relative per capita income in either USD exchange rates or PPP-based exchange rates.

One characteristic of estimating a pooled OLS regression is that it forces the intercept term to be the same across countries, and assumes that the error term is distributed identically over the entire sample. Because this is something that should be tested, rather than assumed, we also estimated random effects and fixed effects regressions. The former assumes that the individual specific error is uncorrelated with the right hand side variables, while the latter is efficient when this correlation is non-zero. ${ }^{10}$

Random effects regressions do not yield substantially different results from those obtained using pooled OLS. Interestingly, when allowing the within and between coefficients to differ, we do find differing effects. In particular, with US\$ based per capita GDP, the within effect is much stronger than the between. This divergence is likely picking up short term effects, where output growth is correlated with other variables pushing up currency values. This pattern, however, is not present in results derived from the PPP-based output data.

Interestingly, the estimated elasticity of the price level with respect to per capita income does not appear to be particularly sensitive to measurements of per capita income. In all cases, the elasticity estimate is always around $0.25-0.39$, which compares

\footnotetext{
$9 \quad \beta_{0}$ can take on currency specific values if a fixed effects specification is implemented. Similarly, the error term is composed of a currency specific and aggregate error if the pooled OLS specification is dropped.

10 Since the price levels being used are comparable across countries, in principle there is no need to incorporate country-specific constants as in fixed effects or random effects regressions. In addition, fixed effects estimates are biased in the presence of serial correlation, which is documented in the subsequent analysis.
} 
favorably with Frankel's (2006) 1990 and 2000 year cross-section estimates of 0.38 and 0.32 , respectively. ${ }^{11}$

One of the key emphases of our analysis is the central role accorded the quantification of the uncertainty surrounding the estimates. That is, in addition to estimating the economic magnitude of the implied misalignments, we also assess whether the implied misalignments are statistically different from zero. In Figures 3 and 4, we plot the actual and resulting predicted rates and standard error bands. To simply presentation, we focus on results derived from the PPP-based data since the results pertaining to US\$ based per capita GDP data are qualitatively similar.

It is interesting to consider the path that the RMB has traced out in the graph. It begins the sample as overvalued, and over the next three decades it moves toward the predicted equilibrium value and then overshoots, so that, by 2004 , it is substantially undervalued - by $53 \%$ in level terms (greater in log terms). It is indeed a puzzle that the RMB path is different from the one predicted by the Balassa-Samuelson hypothesis. In comparing the observations at 1975 and 2004, we found that countries including Indonesia, Malaysia, and Singapore also experienced an increase in their income but a decrease in their real exchange rates. On the other hand, Japan - a country typically used to illustrate the Balassa-Samuelson effect, has a positive real exchange rate - income relationship. The phenomenon warrants further analysis in a future study.

In this context, we make two observations about these misalignment estimates. First, the RMB has been persistently undervalued by this criterion since the mid-1980s, even in 1997 and 1998, when China was lauded for its refusal to devalue its currency despite the threat to its competitive position.

Second, and perhaps most importantly, in 2004, the RMB was more than one standard error - but less than two standard errors - away from the predicted value, which in the present context is interpreted as the "equilibrium" value. In other words, by the standard statistical criterion that applied economists commonly appeal to, the RMB is not undervalued (as of 2004) in a statistically significant sense. The wide dispersion of

11 Note that, in addition to differences in the sample, our estimates differ from Frankel's in that we measure each country's (logged) real GDP per capita in terms relative to the US rather than in absolute terms. 
observations in the scatter plots should give pause to those who would make strong statements regarding the exact degree of misalignment.

\subsection{Controlling for Serial Correlation}

Notice that the deviations from the conditional mean are persistent; that is, deviations from the real exchange rate - income relationship identified by the regression are persistent, or exhibit serial correlation. It has an important implication for interpreting the degree of uncertainty surrounding these measures of misalignment. Frankel (2006) makes a similar observation, noting that half of the deviation of the RMB from the 1990 conditional mean exists in 2000. We estimate the autoregressive coefficient in our sample at approximately 0.89 to 0.91 (derived from USD- and PPP-based per capita income figures, respectively) on an annual basis. A simple, ad hoc adjustment based upon the latter estimate suggests that the standard error of the regression should be adjusted upward by a factor equal to $\left[1 /\left(1-\hat{\rho}^{2}\right)\right]^{0.5} \approx 2$.

To provide a temporal dimension of the estimated misalignment, we trace the evolution of the RMB level over time, its predicted value, and the associated confidence bands adjusted to account for the serial correlation in Figure 5. The figure shows a striking feature - after controlling for serial correlation, the actual value of the RMB is always within one standard error prediction interval surrounding the (predicted) equilibrium value in the last 20 plus years! Combining this result and the large data dispersion observed in Figure 4, we have the impression that the data are not informative for a sharp misalignment inference - not just for the recent period but for the entire sample period.

While the ad hoc adjustment procedure offers a more accurate assessment of the degree of uncertainty surrounding the predicted level of misalignment, it gives no information on the estimated real exchange rate-relative income relationship that is free of serial correlation effects. In order to obtain estimates that are statistically correct in the presence of serial correlation, we implemented a panel version of the Prais-Winsten procedure. ${ }^{12}$ The results are reported in the third column of Table 1.

12 In essence, the Prais-Winsten method is an efficient procedure that incorporates serial correlation into the estimation process. We also implemented the Arellano-Bond 
The pooled OLS estimate using PPP-based per capita income indicates a short run elasticity of 0.15 , which is about one-half of the estimate without the serial correlation adjustment. The implied rate of adjustment is about 0.93 and the implied long-run elasticity is an implausibly high value of around 2. Relaxing the assumption that the errors are the same across time and individual countries (i.e., the random effects regression), we obtain a smaller short-run and hence long-run elasticity -0.13 and 1.8 , respectively. Since the Hausman tests rejects the orthogonality of the constant and the right hand side variable, we also consider the fixed effects regression results. These indicate the cross-country elasticity as being 0.4 (that is the "between" effect), and the short run elasticity 0.04 (not significant).

Figure 6 shows the predicted RMB exchange rate based upon the pooled OLS estimates. Two observations are in order. First, for most of the sample period, the actual RMB value is within the one standard error prediction band - that is, the currency is insignificantly different from its predicted equilibrium value. The result is similar to the one depicted in Figure 5. Second, while the actual RMB value has been slightly below its predicted value since the 1997 Asian financial crisis year, the two values virtually have converged by 2004 and there is little indication of undervaluation. In fact, the 2004 actual value slightly exceeds the predicted one; suggesting an overvaluation of 0.2 percent albeit statistically insignificant. The surprising result is a consequence of taking serial correlation seriously - that is dealing with the high degree of persistence in the real exchange rate over time.

That being said, most of the time, the actual exchange rate is within about one standard error of the predicted, suggesting that the case for overvaluation is about as strong (or weak) as the case for undervaluation. In other words, we can have little

approach that introduces lagged dependent variables into the model to account for serial correlation. The validity of the Arellano-Bond depends on the use of "good" instruments and the assumption that the number of time series observation is greater than the number of cross-sectional variables. In the current case, the choice of instruments is a practical issue and the time series dimension is smaller than the number of economies. In any case, the Arellano-Bond result is qualitatively similar to the one based on the ad hoc AR1 adjustment - the procedure gives a much larger standard error for a comparable estimate of undervaluation estimate given in Figure 3. These results are not presented for brevity. 
certitude about RMB misalignment using this oft-used cross-country relationship between the real exchange rate and per capita income, once issues of serial correlation are explicitly accounted for.

It is well-known that serial correlation, if not appropriately corrected for, can lead to biased estimates and unreliable inferences. In the current exercise (illustrated in Figures 4 and 5), serial correlation is handled using two different approaches and yet

yield similar inferences regarding RMB misalignment. Despite the apparent RMB undervaluation, both cases show that adjustment for serial correlation effects results in a much weaker case for a significantly undervalued RMB. In the next two sections, we shift our attention to other factors that might mediate the real exchange rate-relative income relationship.

\section{Analyses of Subsamples}

In the current and subsequent sections, we consider several variations of the basic bivariate structure in order to assess the robustness of our findings. Again, to simplify presentation and conserve space, we focus on results pertaining to PPP-based output data. In general, the results are quite robust to the choice of output data. The omitted results are available upon request.

\subsection{Developed/Developing and Income Stratifications}

In Table 2, we report the results obtained from developed and developing countries. Interestingly, we find that the pooled OLS estimate is much larger for the developed countries than for the developing. This is somewhat surprising, given the widespread belief that Balassa-Samuelson effects are more pronounced in developing countries. Furthermore, the F-test indicates that the GDP effects are significantly different across the two country groups.

We investigate further by estimating random effects models. For developed countries, the GDP effect under the random effects model is substantially smaller than the one under the OLS setting; 0.19 versus 0.75 . The change in the case of developing countries is much less dramatic, and the random effects model gives a stronger GDP effect. Interestingly, the random effects specification reverses the relative size of the GDP 
effect so that now the slope coefficient is greater in developing countries. Since the Hausman test fails to reject the exogeneity assumption, we can be relatively confident that these values are representative.

Using the developing country pooled OLS estimates, we find that the RMB is $51 \%$ misaligned as of 2004 (see Figure 7). However, the actual rate is still within two standard errors of the predicted.

When we break the sample into finer categories - namely into high, middle, and low income groupings - we find a pattern wherein the pooled OLS estimates are highest in the highest income group, and declines with income grouping (Table 3). A formal Ftest confirms that the estimated GDP effects are significantly different across these income groups.

Moving to the random effects specifications, which appear to be appropriate for the high and middle income groupings, one finds that the elasticities are about the same, at 0.16 versus 0.14 . Table 4 also shows the between effects' estimate of the exchange rate-income elasticity of -0.26 for low income countries, while the within effect is about a half. In other words, for low income countries, there is substantial variation over time due to income changes.

Using the middle income country estimates, we estimate the extent of RMB undervaluation as close to $48 \%$ at 2004 , but still within the two standard error band (See Figure 8).

\subsection{The East Asian Economies}

One question that stands out in our view is whether East Asia as a whole is distinguished from other countries in terms of its experience with real exchange rates. In addition, we have some a priori idea that Africa at the very least behaves in a different way than other developing countries. Hence, we also stratify the sample by regional grouping. The estimation results in Table 4 and the F-test statistics in its Notes section provide some evidence that there are indeed significant regional differences.

Asia and Latin America do not differ substantially in terms of the pooled OLS estimates, while Africa's coefficient is somewhat lower. The random effects specification is rejected by Hausman tests; looking to the fixed effects regressions, we find the pattern 
mentioned in the previous section repeated. That is, in the relatively higher income Asia grouping, the between coefficient is fairly high, while the within is actually negative. ${ }^{13}$ The Latin America grouping exhibits about equally sized coefficients, while for Africa, the within coefficient dwarfs the nonsignificant between coefficient. In sum, we conclude that it is important to differentiate between country groupings.

Using the Asia-specific coefficients, we find a $49 \%$ undervaluation for RMB, once again within the two standard error band (See Figure 9).

\subsection{Different Sample Periods}

A third dimension along which to split the sample is along the time dimension. In particular, we use a break point of 1989/90, approximately halfway through the full sample.

The results reported in Table 5 are quite interesting. According to the OLS results, the slope coefficient is larger, by about $75 \%$, in the more recent period. ${ }^{14}$ However, this result does not stand up to allowing for random effects. Since the Hausman test rejects in the second subsample, we discuss the fixed effects estimates, which indicate the between effect has indeed been quite strong over the last fifteen years, while the within effect is essentially zero. That is important, as we consider the fact that Chinese per capita income has been rising rapidly over time. These results suggest that the average per capita income is what is important in assessing under or overvaluation. Using the pooled OLS estimate results, we find the RMB is undervalued by $67 \%$ and, again, the estimated undervaluation is within the two standard error band (see Figure 10).

Although our sample stratification scheme is not exhaustive, the results so far inspire two general observations. One is that the GDP effect in the real exchange raterelative income regression varies across country groups and across historical periods. Second, the results from these subsamples do not change the basic message developed in the last section - that is, the case for RMB undervaluation is not that strong once

\footnotetext{
13 See Devereux (1999) for an early observation of this pattern.

14 The slope coefficient estimates from year-by-year regressions show a similar upward trend. The slope coefficient starts with a low of 0.14 at 1975 and moves up gradually to the high of 0.39 at 1995 . Then it stays quite steady around the level of 0.36 for the rest of the sample.
} 
sampling uncertainty is taken into consideration. Further, when we accounted for serial correlation in the estimation process, the magnitude of undervaluation is substantially reduced.

\section{Beyond the Bivariate Framework}

\subsection{Demographics, Policy, and Financial Development}

One remarkable feature of the previous results is the finding that the RMB is almost always undervalued by close to $50 \%$ in log terms - regardless of the sample used to make the assessment; moreover the null of no undervaluation cannot typically be rejected. These findings could be driven by the fact that the bivariate framework does not explicitly consider (short-run) internal and external imbalances which might be associated with certain variables. In this context, the serial correlation in the error term could signify the omission of serially correlated explanatory variables. Even though we can econometrically fix the serial correlation problem (see Section 3.3), it might be preferable to identify the relevant variables, in order to resolve the problem in economic terms. These points suggest that one might want to broaden the set of determinants.

Once one moves away from a simple world where the per capita income differential is a proxy for Balassa-Samuelson effects, a whole universe of additional determinants suggest themselves. In particular, if the income variable proxies not only for productivity differentials, but also non-homotheticity of preferences, savings propensities, or impediments to the free flow of capital, then one would wish to include variables that pertain to these factors. Hence we augment the relative per capita income with demographics - under 14 and over 65 dependency ratios - and with an index of capital account openness developed by Chinn and Ito (2006). We include a government deficit variable because Chinn and Prasad (2003) find that it explains part of current account balances over the medium term. Finally, financial deepening is proxied by an M2/GDP ratio.

The results are reported in the first column of Table 6. Interestingly, the elasticity of the price level with respect to relative income is not drastically altered, relative to the original full-sample bivariate regression estimates (Table 1). Moreover, the additional 
variables enter in with statistical significance (with the exception of the government deficit variable).

Overall, the results suggest that capital account openness increases the equilibrium value of the currency. Financial deepening also has a positive effect. This result does not appear to be the consequence of a spurious "credit boom" effect, since the "between" coefficient is more important than the "within" (or over time) coefficient.

In Figure 11, we plot the time profile of the implied RMB undervaluation using the pooled OLS specification. The graphs show that a nominal undervaluation greater than one standard error starting 1994, the year China moved from a dual to a unified exchange rate arrangement. Nonetheless, the estimated degree of undervaluation is usually within the two standard error prediction band and is only slight outside the band in 2004. The actual RMB value is just outside the two standard prediction error bands at the very end of the sample period; in this instance the undervaluation is $76 \%$. Apparently, the inclusion of these additional explanatory variables tends to indicate greater misalignment. ${ }^{15}$

\subsection{Capital Account Openness and Institutions}

One oft-heard argument is that the Chinese economy is special - namely it is one that is characterized by extreme corruption, as well as an extensive capital control regime. We investigate whether these two particular aspects are of measurable importance in the determination of exchange rates and, if so, whether our conclusions regarding RMB misalignment are altered as a consequence.

We augment the basic real exchange rate-relative income relationship with the aforementioned Chinn-Ito capital account openness index. In addition we use the International Country Risk Guide's (ICRG) Corruption Index as our measure of institutional development (where higher values of the index denote less corruption).

The results are reported in the second column of Table 6 . Since the corruption index is very slow moving, with a small time-varying component, it does not make too much sense to look at the fixed effects and random effects estimates. Focusing on the

15 Although the use of a fixed effects model yields a much smaller misalignment in this, and the subsequent, case. These results are available upon request. 
pooled estimates from PPP-based output data, one observes that the per capita income coefficient is largely in line with the previous estimates. Similarly, capital account openness enters in positively, but not significantly. On the other hand, the (lack of) corruption enters in positively only when income is measured in PPP terms: The less corruption, the stronger the local currency.

We include an interaction term to allow for varying effects of capital openness in the presence of corruption. The estimates indicate that when capital account openness increases in absence of corruption, then the currency appreciates. This finding implies that when the capital account openness increases in the presence of relatively high levels of corruption, the equilibrium value of the currency is weaker.

When we examine the time profile of the implied RMB undervaluation under the current model specification, we find that the standard error bands are wider, and the estimated degree of undervaluation commensurately smaller (see Figure 12). In log terms, the undervaluation in 2004 is somewhat smaller than in the previous case, $72 \%$. In other words, to the extent that lack of transparency is given at an instant, the RMB is still not undervalued at conventional levels of statistical significance.

In sum, these control variables help explain a small portion of the estimated undervaluation reported in the previous section. However, when sampling uncertainty is taken into consideration, we still end up with the same inference: there is no strong and consistent statistical evidence of RMB misalignment in the recent sample period. Rather, the actual RMB value is in almost every case within the corresponding prediction interval.

It is also noted that, despite the added variables, serial correlation is again found in specifications considered in Section 5.1 and 5.2. Further, results from the PraisWinsten procedure that controls for serial correlation give a much smaller estimate of RMB undervaluation. To illustrate the point, we plot the results based on the PraisWinsten procedure in Figures 13 and 14. Indeed, the decline in the estimated degree of undervaluation is quite substantial. The Prais-Winsten procedure yielded an estimated $4.2 \%$ undervaluation compared with $76 \%$ in Figure 11 and an estimated $8.7 \%$ undervaluation compared with $72 \%$ in Figure 12 . Both serial correlation adjusted estimates are well within the one standard error band. 


\section{Discussions}

In the current debate regarding RMB valuation, some consider the large current account surplus a clear evidence of substantial RMB undervaluation. We recognize the contentious nature of the debate on the causes of, say, the US current account deficits with China and the related implications for exchange rate valuation. In Section 5, we included government deficit, financial deepening, and demographic variables in the list of explanatory variables to account for the effects of current account balances on exchange rates indirectly. ${ }^{16}$

As a robustness check, we also considered the direct effect of a current account balance variable. Specifically, the lagged value of the current account to GDP ratio relative to that of the US was added to all specifications presented thus far. To save space, we only report results pertaining to the two specifications considered in Section 5 to illustrate the point (see Table 7). The plots derived for the two specifications with the lagged current account variables are presented in Figures 15 and 16. In general, the current account balance variable is statistically significant but does not noticeably alter other coefficient estimates. One puzzling observation is that its sign changes across model specifications. ${ }^{17}$ Comparing Figures 13 and 14 with Figures 15 and 16, we find that the inclusion of the current account balance variable does not change the inference of the degree of RMB undervaluation.

In passing, we would like to mention that China's rapid international reserve accumulation is another oft-cited evidence of RMB undervaluation. That particular argument, however, may require additional analysis. Prasad and Wei (2005), for example, show that changes in the capital account, rather than the current account, contributed to China's recent reserve buildup and, thus, the buildup may be self-fulfilling.

16 The indirect approach avoids the technical issue of endogeneity. See, for example, Chinn and Prasad (2003) for determinants of current account balances.

17 Apparently, the association between the current account and the real exchange rate is an unsettled issue. For example, Rogoff (1996, p. 663) points out that "from a theoretical perspective, virtually any correlation between the current account and the real exchange rate can be easily rationalized." 
While the empirical results thus far point to the difficulty in establishing the claim that RMB is significantly undervalued, it is imperative to recognize that these results $d o$ not constitute evidence of no undervaluation. Indeed, the statistical evidence is so "weak" that we cannot reject a wide range of hypotheses. For instance, we could not reject the null hypothesis that the RMB is $20 \%$ undervalued. In other words, the empirical relationship is very imprecisely estimated. That is, the empirical models and data are not sharp enough to allow a definite statistical conclusion. A corollary is that it is hard to formulate an adjustable-peg policy because it is hard to statistically establish evidence against a misaligned peg.

Our bivariate estimation results identify 83 significant overvaluation cases and 78 significant undervaluation cases. Most of these instances correspond to extreme political and economic conditions. Perhaps a reflection of the imprecision of the estimats, real exchange rates of Thailand in 1997 and Argentina in 2001 are not identified to be significantly misaligned. ${ }^{18}$

This imprecision appears not to be unique to the current exercise, even though it is often overlooked. Dunaway, Leigh, and Li (2006) make a similar observation from a different perspective. These authors, using the RMB as an example, show that equilibrium real exchange rate estimates obtained from the various approaches and models commonly used in the literature exhibit substantial variations in response to small perturbations in model specifications, explanatory variable definitions, and time periods. That is, inferences regarding misalignment are very sensitive to small changes in the way the equilibrium exchange rate is estimated.

Data reliability makes the situation even murkier. The quality of data from, say, emerging markets is always a concern. Given its growing significance in the world economy, the reliability of China's official data is a subject of intense debate. At the end of 2005, China revised its GDP figures after a year long nationwide economic census.

18 The bivariate estimation results indicate that a) the Thai baht was undervalued by $13.1 \%$ in 1996, and b) the Argentine peso was undervalued by $2.9 \%$ in 2001 . On the other hand, results from the extended models considered in Section 5 show that the Argentine peso was overvalued by $12.1 \%$ in 2001 while the Thai baht was undervalued. The finding of small deviations for the Thai baht is not atypical; see e.g. Chinn (2000b). 
Specifically, the 2004 figure was revised upward by $17 \% .{ }^{19}$ Thus, one has to interpret estimates of misalignment, including the ones reported in the current exercise, with great caution.

\section{Summary and Some Concluding Thoughts}

In the current exercise, we undertake an objective evaluation of the thesis of RMB undervaluation using conventional empirical methods of inference. Anticipating the problems associated with using standard exchange rate models - including the FEER/BEER models commonplace in the practitioner literature - to explain exchange rate behavior of developing and transition economies, we opt to rely upon the more straightforward and robust relative price and relative output framework.

We extend the existing literature along several dimensions. First, we analyze relative price and relative output relationship in a panel time-series cross-section framework in order to improve power, and so as to be able to trace out the time profile of misalignment measures. Second, we base our inferences on the property of misalignment estimates. In particular, we explicitly account for the effects of sampling uncertainty and serially correlated errors on our inferences regarding the extent of currency misalignment. Third, we examine the stability of the relative price and relative output relationship and the corresponding implications for the analysis of misalignments.

Under the basic specification and some of its variants, the RMB is found to be undervalued - a result that is consistent with the conventional wisdom. The result, however, does not survive a close scrutiny of the empirical evidence.

One general observation is that, when one implements the standard operating procedure of accounting for sampling uncertainty in making inferences, there is no evidence supporting the claim that RMB is substantially undervalued, using conventional significance levels. Depending on the specification under examination, the actual RMB value is usually within one or two standard errors of its predicted level. Our inability to establish a convincing statistically significant result applies to most, if not all, the models and time periods under consideration. We also believe that our results accounting for serial correlation are extremely important, and bear upon the interpretation of the extant

19 The World Bank data used here do not incorporate this round of data revision. 
literature. With technical procedures controlling for serial correlation effects, the evidence for RMB undervaluation is substantially weakened.

A by-product of our exercise is the finding that the relative price and relative output relationship is neither constant over time nor across country groups. The wide diversity of estimated output effects implies variously higher or lower misalignment estimates, but it does not alter the basic result that the RMB is not significantly different from its predicted equilibrium value.

It is also important to make it clear that we do not claim that the relative price and relative output relationship is the most appropriate framework for studying the RMB exchange rate behavior. Even though the framework we have adopted has certain advantages over some standard exchange rate models in cross-country analysis that involves transitional and developing economies, more effort has to be made to capture the special features of these economies. The addition of several control variables suggested by the literature might be a good first (empirical) step in the right direction. However, we admit that a more elaborate theoretical framework would be very helpful in guiding future work.

For instance, the finding that capital account openness and (the lack of) corruption matters for the level of the exchange rate suggests that our understanding of when a currency is misaligned is highly circumscribed. Other factors that warrant attention include the large buildup of nonperforming loans and the structural weakness of the financial sector. These factors, combined with corporate governance and labor market rigidity, are likely to have significant implications for the equilibrium value of RMB which are not fully captured in the current exercise.

It is worth repeating that our results highlight the difficulty of delivering a clear statistical evidence of RMB undervaluation, which is in accordance with the well-known result that it is quite difficult to model exchange rates in general. But these results do not necessarily mean that there is no undervaluation.

In a broader perspective, the finding of a highly uncertain equilibrium real exchange rate buttresses the case for a prudent, cautious exchange rate policy that avoids abrupt changes in the Chinese economy. Given its limited financial market capacity and structural rigidity, an abrupt change in the Chinese exchange rate policy could lead to 
some significant challenges to economic growth and stability. China's measured approach to exchange rate regime liberalization, coupled with increasing imports and domestic consumption, might facilitate a resolution of global imbalances.

However, in our view, this goal will only be achieved if combined with appropriate policy changes in other countries (e.g. the US). 


\section{References}

Balassa, Bela, 1964, “The Purchasing Power Parity Doctrine: A Reappraisal," Journal of Political Economy 72: 584-596.

Beck, Thorsten, Asli Demirgüc-Kunt, and Ross Levine, 2000, "A new database on financial development and structure," Policy Research Paper No. 2147 (Washington, D.C.: World Bank).

Bosworth, Barry, 2004, "Valuing the Renminbi," paper presented at the Tokyo Club Research Meeting, February 9-10.

Cairns, John, 2005, “China: How Undervalued is the CNY?” IDEAglobal Economic Research (June 27).

Canzoneri, Matthew, Robert Cumby and Behzad Diba, 1996, "Relative Labor Productivity and the Real Exchange Rate in the Long Run: Evidence for a Panel of OECD Countries," Journal of International Economics 47(2): 245-66.

Cheung, Yin-Wong, Menzie Chinn and Eiji Fujii, forthcoming, "The Illusion of Precision and the Role of the Renminbi in Regional Integration," in Koichi Hamada, Beate Reszat and Ulrich Volz (editors), Prospects for Monetary and Financial Integration in East Asia: Dreams and Dilemmas.

Chinn, Menzie, 2000a, “The Usual Suspects? Productivity and Demand Shocks and AsiaPacific Real Exchange Rates," Review of International Economics 8(1) (February): 20-43.

Chinn, M.D., 2000b, Three Measures of East Asian Currency Overvaluation, Contemporary Economic Policy 18 (2), 205-214.

Chinn, Menzie and Hiro Ito, 2006, "What Matters for Financial Development? Capital Controls, Institutions and Interactions," Journal of Development Economics 61(1): 163-192.

Chinn, Menzie and Eswar Prasad, 2003, "Medium-Term Determinants of Current Accounts in Industrial and Developing Countries: An Empirical Exploration," Journal of International Economics 59(1) (January): 47-76.

Coudert, Virginie and Cécile Couharde, 2005, "Real Equilibrium Exchange Rate in China," CEPII Working Paper 2005-01 (Paris, January). 
DeGregorio, Jose and Holger Wolf, 1994, "Terms of Trade, Productivity, and the Real Exchange Rate," NBER Working Paper \#4807 (July).

Devereux, Michael B., 1999, "Real Exchange Rates and Growth: A Model of East Asia," Review of International Economics 7: 509-521.

Dunaway, Steven, Lamin Leigh and Xiangming Li, 2006, "How Robust are Estimates of Equilibrium Real Exchange Rates: The Case of China," IMF Working Paper.

Dunaway, Steven and Xiangming Li, 2005, “Estimating China's Equilibrium Real Exchange Rate," IMF Working Paper .

Fernald, John, Hali Edison, and Prakash Loungani, 1999, "Was China the First Domino? Assessing Links between China and Other Asian Economies," Journal of International Money and Finance 18 (4): 515-535.

Frankel, Jeffrey, 2006, "On the Yuan: The Choice between Adjustment under a Fixed Exchange Rate and Adjustment under a Flexible Rate," CESifo Economic Studies 52(2): 246-75.

Funke, Michael and Jörg Rahn, 2005, "Just how undervalued is the Chinese renminbi?" World Economy 28: 465-89.

Goldstein, Morris, 2004, "China and the Renminbi Exchange Rate," in C. Fred Bergsten and John Williamson (editors), Dollar Adjustment: How Far? Against What? Special Report No. 17 (Washington, D.C.: Institute for International Economics, November).

Government Accountability Office, 2005, International Trade: Treasury Assessments Have Not Found Currency Manipulation, but Concerns about Exchange Rates Continue," Report to Congressional Committees GAO-05-351 (Washington, D.C.: Government Accountability Office, April).

Hinkle, Lawrence E. and Peter J. Montiel, 1999, Exchange Rate Misalignment (Oxford University Press/World Bank, New York).

Hsieh, David, 1982, "The Determination of the Real Exchange Rate: The Productivity Approach, " Journal of International Economics 12(2): 355-362.

Krueger, Anne O., 1983, Exchange-Rate Determination (Cambridge, UK: Cambridge University Press). 
Rogoff, K., 1996, The Purchasing Power Parity Puzzle, Journal of Economic Literature 34 (June), 647-668.

Prasad, Eswar and Shang-Jin Wei, 2005, “The Chinese Approach to Capital Inflows:

Patterns and Possible Explanations," NBER Working Paper No. 11306 (April).

Salter, Wilfred A., 1959, "Internal and External Balance: The Role of Price and Expenditure Effects," Economic Record 35: 226-38.

Samuelson, Paul, 1964, "Theoretical Notes on Trade Problems," Review of Economics and Statistics 46: 145-154.

Summers, Robert and Alan Heston, 1991, "The Penn World Table (Mark 5): An Expanded Set of International Comparisons," Quarterly Journal of Economics 106: 327-68.

Swan, Trevor, 1960, "Economic Control in a Dependent Economy," Economic Record 36: 51-66.

Wang, Tao, 2004, "Exchange Rate Dynamics," in Eswar Prasad (editor), China's Growth and Integration into the World Economy, Occasional Paper No. 232 (Washington, D.C.: IMF), pp. 21-28.

Zhang, Zhichao, 2001, "Real Exchange Rate Misalignment in China: An Empirical Investigation," Journal of Comparative Economics 29, 80-94. 


\section{Appendix 1: Data and Sources}

For Section 2:

The nominal Renminbi exchange rate is the bilateral period average, expressed against the US\$ (in \$/f.c.u.), obtained from the IMF's International Financial Statistics, and from Hali Edison, for the "adjusted" exchange rates (Fernald et al., 1999). The CPI's are drawn from the CEIC database, extrapolated for 2004 and 2005 by using the CPI growth rates reported in IFS. The CPI deflated trade weighted exchange rate is drawn from IFS.

\section{For Section 3:}

The data for macroeconomic aggregates are drawn mostly from the World Bank's World Development Indicators. These include demographic variables, per capita income and government deficits. Financial development indicators, including lending, stock and bond market capitalization, are drawn from the Beck et al. (2000). The capital controls index is from Chinn and Ito (2006). The (inverse) corruption index is drawn from the International Country Risk Guide. Data for Taiwan are drawn from the Central Bank of China, International Centre for the Study of East Asian Development, and Asian Development Bank, Key Indicators of Developing Asian and Pacific Countries. For some variables, 2004 data are drawn from the IMF, World Economic Outlook (April) database. 
Table 1: The panel estimation results of the real exchange rate - income relationship

\begin{tabular}{|c|c|c|c|c|c|c|c|c|c|c|c|c|}
\hline & \multicolumn{4}{|c|}{ USD-based GDP } & \multicolumn{4}{|c|}{ PPP-based GDP } & \multicolumn{4}{|c|}{ PPP-based GDP (Prais-Winsten) } \\
\hline & $\begin{array}{l}\text { Pooled } \\
\text { OLS }\end{array}$ & Between & $\begin{array}{l}\text { Fixed } \\
\text { effects } \\
\text { (Within) }\end{array}$ & $\begin{array}{l}\text { Random } \\
\text { effects }\end{array}$ & $\begin{array}{l}\text { Pooled } \\
\text { OLS }\end{array}$ & Between & $\begin{array}{l}\text { Fixed } \\
\text { effects } \\
\text { (Within) }\end{array}$ & $\begin{array}{l}\text { Random } \\
\text { effects }\end{array}$ & $\begin{array}{l}\text { Pooled } \\
\text { OLS }\end{array}$ & Between & $\begin{array}{l}\text { Fixed } \\
\text { effects } \\
\text { (Within) }\end{array}$ & $\begin{array}{l}\text { Random } \\
\text { effects }\end{array}$ \\
\hline GDP per & $0.249 * *$ & $0.254 * *$ & $0.391 * *$ & $0.297 * *$ & $0.299 * *$ & $0.300 * *$ & $0.273 * *$ & $0.284 * *$ & $0.147^{* *}$ & $0.396^{* *}$ & 0.036 & $0.132 * *$ \\
\hline capita & $(0.003)$ & $(0.015)$ & $(0.029)$ & $(0.012)$ & $(0.006)$ & $(0.028)$ & $(0.031)$ & $(0.017)$ & $(0.021)$ & $(0.028)$ & $(0.025)$ & $(0.021)$ \\
\hline Constant & $\begin{array}{l}-.016^{* * *} \\
(0.008)\end{array}$ & $\begin{array}{l}-.036 \\
(0.050)\end{array}$ & - & $\begin{array}{l}0.084 \\
(0.042)\end{array}$ & $\begin{array}{l}-.134 * * \\
(0.011)\end{array}$ & $\begin{array}{l}-.177 * * \\
(0.061)\end{array}$ & - & $\begin{array}{l}-.204^{* *} \\
(0.043)\end{array}$ & $\begin{array}{l}-.026^{* * *} \\
(0.002)\end{array}$ & $\begin{array}{l}0.001 \\
(0.004)\end{array}$ & - & $\begin{array}{l}-.027 * * \\
(0.003)\end{array}$ \\
\hline $\begin{array}{l}\text { Adjusted } \mathrm{R}^{2} \\
\text { F-test } \\
\text { statistic }\end{array}$ & 0.496 & 0.617 & $\begin{array}{l}0.763 \\
29.468 * *\end{array}$ & 0.496 & 0.349 & 0.413 & $\begin{array}{l}0.754 \\
42.647 * *\end{array}$ & 0.349 & 0.012 & 0.389 & $\begin{array}{l}0.021 \\
1.218^{*}\end{array}$ & 0.012 \\
\hline $\begin{array}{l}\text { Hausman } \\
\text { test statistic }\end{array}$ & & & & $11.873 * *$ & & & & 0.167 & & & & $39.384 * *$ \\
\hline $\begin{array}{l}\text { Number of } \\
\text { observations }\end{array}$ & 4018 & & & & 4018 & & & & 3958 & & & \\
\hline
\end{tabular}

Notes: The data covers 160 countries over the maximum of a thirty-years period from 1975 to 2004 . The panel is unbalanced due to some missing observations. ${ }^{* *}$ and $*$ indicate $1 \%$ and $5 \%$ levels of significance, respectively. Heteroskedasticity-robust standard errors are given in parentheses underneath coefficient estimates. For the fixed effects models, the F-test statistics are reported for the null hypothesis of the equality of the constants across all countries in the sample. For the random effects models, the Hausman test statistics test for the independence between the timeinvariant country-specific effects and the regressor.

The third column labeled (Prais-Winsten) gives estimates from data with serial correlation removed using the Prais-Winsten method. The AR1 coefficient estimate for the Prais-Winsten transformation is 0.951. 
Table 2: The panel estimation results for developed versus developing country samples

\begin{tabular}{|c|c|c|c|c|c|c|c|c|}
\hline & \multicolumn{4}{|c|}{ Developed countries } & \multicolumn{4}{|c|}{ Developing countries } \\
\hline & $\begin{array}{l}\text { Pooled } \\
\text { OLS }\end{array}$ & Between & $\begin{array}{l}\text { Fixed } \\
\text { effects } \\
\text { (Within) }\end{array}$ & $\begin{array}{l}\text { Random } \\
\text { effects }\end{array}$ & $\begin{array}{l}\text { Pooled } \\
\text { OLS }\end{array}$ & Between & $\begin{array}{l}\text { Fixed } \\
\text { effects } \\
\text { (Within) }\end{array}$ & $\begin{array}{l}\text { Random } \\
\text { effects }\end{array}$ \\
\hline GDP per capita & $\begin{array}{l}0.749 * * \\
(0.049)\end{array}$ & $\begin{array}{l}0.898 * * \\
(0.144)\end{array}$ & $\begin{array}{l}-.019 \\
(0.073)\end{array}$ & $\begin{array}{l}0.187 * \\
(0.076)\end{array}$ & $\begin{array}{l}0.233 * * \\
(0.008)\end{array}$ & $\begin{array}{l}0.238 * * \\
(0.035)\end{array}$ & $\begin{array}{l}0.294 * * \\
(0.032)\end{array}$ & $\begin{array}{l}0.276 * * \\
(0.019)\end{array}$ \\
\hline Constant & $\begin{array}{l}0.209 * * \\
(0.016)\end{array}$ & $\begin{array}{l}0.257 * * \\
(0.053)\end{array}$ & - & $\begin{array}{l}0.031 \\
(0.038)\end{array}$ & $\begin{array}{l}-.298 * * \\
(0.018)\end{array}$ & $\begin{array}{l}-.314 * * \\
(0.083)\end{array}$ & - & $\begin{array}{l}-.229 * * \\
(0.052)\end{array}$ \\
\hline $\begin{array}{l}\text { Adjusted } \mathrm{R}^{2} \\
\text { F-test } \\
\text { statistic }\end{array}$ & 0.330 & 0.665 & $\begin{array}{l}0.569 \\
18.536 * *\end{array}$ & 0.330 & 0.192 & 0.266 & $\begin{array}{l}0.670 \\
39.097 * *\end{array}$ & 0.192 \\
\hline $\begin{array}{l}\text { Hausman } \\
\text { test statistic }\end{array}$ & & & & 0.000 & & & & 0.453 \\
\hline $\begin{array}{l}\text { Number of } \\
\text { observations }\end{array}$ & 600 & & & & 3229 & & & \\
\hline
\end{tabular}

Notes: The PPP-based real per capita income is used. The data covers 20 developed and 124 developing countries over the maximum of a thirty-years period from 1975 to 2004 . The panel is unbalanced due to some missing observations. $* *$ and $*$ indicate $1 \%$ and $5 \%$ levels of significance, respectively. Heteroskedasticity-robust standard errors are given in parentheses underneath coefficient estimates. For the fixed effects models, the F-test statistics are reported for the null hypothesis of the equality of the constants across all countries in the sample. For the random effects models, the Hausman test statistics test for the independence between the time-invariant country-specific effects and the regressor. The F-test for the equality of the slope coefficients between the two samples gives a test statistic of 119.931 , which rejects the null hypothesis of equality. 
Table 3: The panel estimation results by income level stratifications

\begin{tabular}{|c|c|c|c|c|c|c|c|c|c|c|c|c|}
\hline & \multicolumn{4}{|c|}{ High income countries } & \multicolumn{4}{|c|}{ Middle income countries } & \multicolumn{4}{|c|}{ Low income countries } \\
\hline & $\begin{array}{l}\text { Pooled } \\
\text { OLS }\end{array}$ & Between & $\begin{array}{l}\text { Fixed } \\
\text { effects } \\
\text { (within) }\end{array}$ & $\begin{array}{l}\text { Random } \\
\text { effects }\end{array}$ & $\begin{array}{l}\text { Pooled } \\
\text { OLS }\end{array}$ & Between & $\begin{array}{l}\text { Fixed } \\
\text { effects } \\
\text { (within) }\end{array}$ & $\begin{array}{l}\text { Random } \\
\text { effects }\end{array}$ & $\begin{array}{l}\text { Pooled } \\
\text { OLS }\end{array}$ & Between & $\begin{array}{l}\text { Fixed } \\
\text { effects } \\
\text { (within) }\end{array}$ & $\begin{array}{l}\text { Random } \\
\text { effects }\end{array}$ \\
\hline GDP per & $0.519 * *$ & $0.650 * *$ & 0.097 & $0.156^{*}$ & $0.249 * *$ & $0.243 * *$ & $0.122 * *$ & $0.137 * *$ & $-.087 * *$ & $-.261 *$ & $0.504 * *$ & $0.414 * *$ \\
\hline capita & $(0.028)$ & $(0.103)$ & $(0.031)$ & $(0.036)$ & $(0.019)$ & $(0.077)$ & $(0.044)$ & $(0.026)$ & $(0.031)$ & $(0.122)$ & $(0.045)$ & $(0.042)$ \\
\hline & $0.127 * *$ & $0.178 * *$ & - & -.026 & $-.384 * *$ & $-.384 * *$ & - & $-.562 * *$ & $-1.297 * *$ & $-1.889 * *$ & - & 0.207 \\
\hline Constant & $(0.013)$ & $(0.050)$ & & $(0.032)$ & $(0.137)$ & $(0.137)$ & & $(0.057)$ & $(0.100)$ & $(0.384)$ & & $(0.143)$ \\
\hline Adjusted $\mathrm{R}^{2}$ & 0.312 & 0.564 & 0.636 & 0.312 & 0.096 & 0.106 & 0.650 & 0.096 & 0.005 & 0.062 & 0.564 & 0.005 \\
\hline $\begin{array}{l}\text { F-test } \\
\text { statistic }\end{array}$ & & & $26.981 * *$ & & & & $40.087^{* *}$ & & & & $33.207 * *$ & \\
\hline $\begin{array}{l}\text { Hausman } \\
\text { test statistic }\end{array}$ & & & & 0.000 & & & & 0.168 & & & & $34.445 * *$ \\
\hline $\begin{array}{l}\text { Number of } \\
\text { observations }\end{array}$ & 875 & & & & 1799 & & & & 1330 & & & \\
\hline
\end{tabular}

Notes: The PPP-based real per capita income is used. The data covers 31 high income countries, 74 middle income countries, and 54 low income countries over the maximum of a thirty year period from 1975 to 2004 . The panel is unbalanced due to some missing observations. ** and * indicate $1 \%$ and $5 \%$ levels of significance, respectively. Heteroskedasticity-robust standard errors are given in parentheses underneath coefficient estimates. For the fixed effects models, the F-test statistics are reported for the null hypothesis of the equality of the constants across all countries in the sample. For the random effects models, the Hausman test statistics test for the independence between the time-invariant country-specific effects and the regressor. The F-test for the equality of the slope coefficients between the samples based on the pooled OLS estimates gives test statistics of 98.483 for high income countries versus middle income countries, 147.143 for high income countries versus low income countries, and 58.053 for middle income countries versus low income countries. In all cases, the null hypothesis of equal slope coefficients is rejected at the conventional level of significance. 
Table 4: The panel estimation results by geographical stratifications

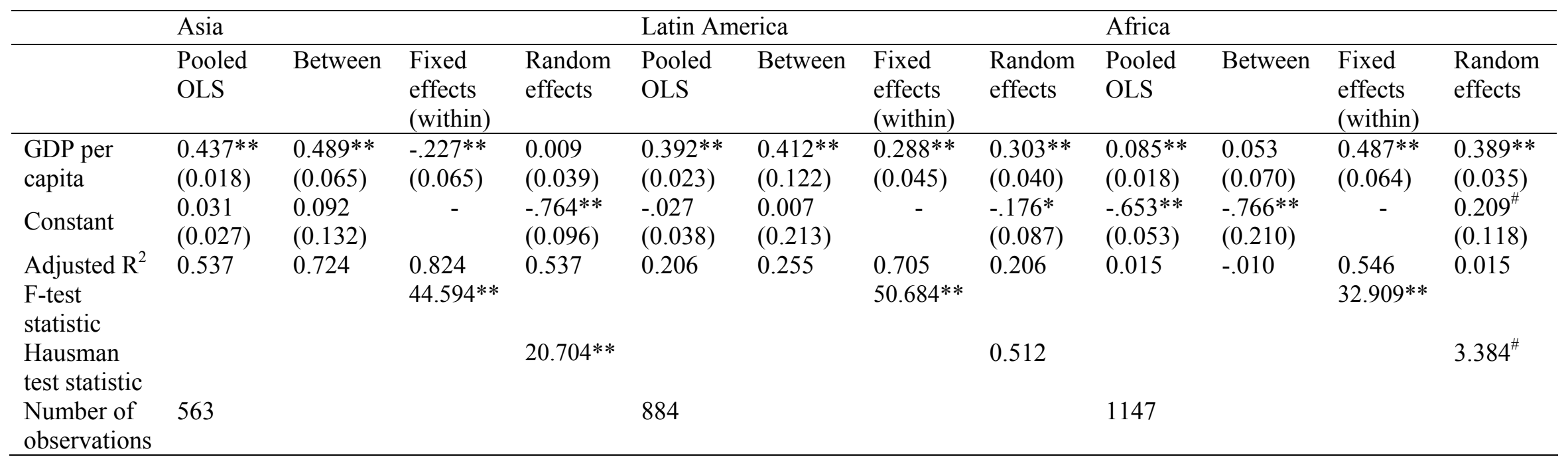

Notes: The PPP-based real per capita income is used. The data covers 22 Asian countries, 31 Latin American countries, and 43 African countries over the maximum of a thirty year period from 1975 to 2004. The panels are unbalanced due to some missing observations. (The country classifications are as defined by the WDI. Asia does not include "South Asia", and Africa does not include "Middle East and North Africa".) ** and * indicate 1\% and $5 \%$ levels of significance, respectively. Heteroskedasticity-robust standard errors are given in parentheses underneath coefficient estimates. For the fixed effects models, the F-test statistics are reported for the null hypothesis of the equality of the constants across all countries in the sample. For the random effects models, the Hausman test statistics test for the independence between the time-invariant country-specific effects and the regressor. The F-test for the equality of the slope coefficients between the samples based on the pooled OLS estimates gives test statistics of 1.351 for Asia versus Latin America, 37.500 for Latin America versus Africa, and 89.698 for Asia versus Africa. In only the latter case, the null hypothesis of equal slope coefficients is rejected at the conventional level of significance. 
Table 5: The panel estimation results for the 1975-1989 and 1990-2004 sub-samples

\begin{tabular}{|c|c|c|c|c|c|c|c|c|}
\hline & \multicolumn{4}{|c|}{ 1975-1989 } & \multicolumn{4}{|c|}{ 1990-2004 } \\
\hline & $\begin{array}{l}\text { Pooled } \\
\text { OLS }\end{array}$ & Between & $\begin{array}{l}\text { Fixed } \\
\text { effects } \\
\text { (Within) }\end{array}$ & $\begin{array}{l}\text { Random } \\
\text { effects }\end{array}$ & $\begin{array}{l}\text { Pooled } \\
\text { OLS }\end{array}$ & Between & $\begin{array}{l}\text { Fixed } \\
\text { effects } \\
\text { (Within) }\end{array}$ & $\begin{array}{l}\text { Random } \\
\text { effects }\end{array}$ \\
\hline $\begin{array}{l}\text { GDP per } \\
\text { capita }\end{array}$ & $\begin{array}{l}0.207 * * \\
(0.009)\end{array}$ & $\begin{array}{l}0.214 * * \\
(0.032)\end{array}$ & $\begin{array}{l}0.283 * * \\
(0.046)\end{array}$ & $\begin{array}{l}0.238 * * \\
(0.024)\end{array}$ & $\begin{array}{l}0.353^{* *} \\
(0.008)\end{array}$ & $\begin{array}{l}0.359 * * \\
(0.026)\end{array}$ & $\begin{array}{l}-.004 \\
(0.056)\end{array}$ & $\begin{array}{l}0.230^{* *} \\
(0.021)\end{array}$ \\
\hline Constant & $\begin{array}{l}-.181 * * \\
(0.017)\end{array}$ & $\begin{array}{l}-.190^{* *} \\
(0.068)\end{array}$ & - & $\begin{array}{l}-.143^{*} \\
(0.055)\end{array}$ & $\begin{array}{l}-.118 * * \\
(0.016)\end{array}$ & $\begin{array}{l}-.118^{\#} \\
(0.059)\end{array}$ & - & $\begin{array}{l}-.369 * * \\
(0.051)\end{array}$ \\
\hline $\begin{array}{l}\text { Adjusted } \mathrm{R}^{2} \\
\text { F-test } \\
\text { statistic }\end{array}$ & 0.209 & 0.251 & $\begin{array}{l}0.781 \\
36.279 * *\end{array}$ & 0.209 & 0.459 & 0.529 & $\begin{array}{l}0.865 \\
43.766 * *\end{array}$ & 0.459 \\
\hline $\begin{array}{l}\text { Hausman } \\
\text { test statistic }\end{array}$ & & & & 1.266 & & & & $20.287 * *$ \\
\hline $\begin{array}{l}\text { Number of } \\
\text { observations }\end{array}$ & 1757 & & & & 2261 & & & \\
\hline
\end{tabular}

Notes: The PPP-based real per capita income is used. The data covers 131 countries over the 1975-1989 period, and 159 countries over the 1990-2004 period. The panels are unbalanced due to some missing observations. $* *, *$ and ${ }^{\#}$ indicate $1 \%, 5 \%$ and $10 \%$ levels of significance, respectively.

Heteroskedasticity-robust standard errors are given in parentheses underneath coefficient estimates. For the fixed effects models, the F-test statistics are reported for the null hypothesis of the equality of the constants across all countries in the sample. For the random effects models, the Hausman test statistics test for the independence between the time-invariant country-specific effects and the regressor. The F-test for the equality of the slope coefficients between the two sub-samples gives a test statistic of 183.677 , which rejects the null hypothesis of equality. 
Table 6: Estimation with control variables

\begin{tabular}{|c|c|c|c|c|c|c|c|c|}
\hline & \multicolumn{4}{|c|}{$\begin{array}{l}\text { demographics, policy, and financial } \\
\text { development }\end{array}$} & \multicolumn{4}{|c|}{ capital account openness and corruption } \\
\hline & $\begin{array}{l}\text { Pooled } \\
\text { OLS }\end{array}$ & Between & $\begin{array}{l}\text { Fixed } \\
\text { effects } \\
\text { (Within) }\end{array}$ & $\begin{array}{l}\text { Random } \\
\text { effects }\end{array}$ & $\begin{array}{l}\text { Pooled } \\
\text { OLS }\end{array}$ & Between & $\begin{array}{l}\text { Fixed } \\
\text { effects } \\
\text { (Within) }\end{array}$ & $\begin{array}{l}\text { Random } \\
\text { effects }\end{array}$ \\
\hline GDP per & $0.257 * *$ & $0.236 * *$ & $0.286 * *$ & $0.264 * *$ & $0.254 * *$ & $0.222 * *$ & $0.185^{* *}$ & $0.268 * *$ \\
\hline capita & $(0.013)$ & $(0.045)$ & $(0.034)$ & $(0.022)$ & $(0.011)$ & $(0.042)$ & $(0.042)$ & $(0.022)$ \\
\hline Popuation & $0.302 * *$ & $0.373 * *$ & 0.035 & $0.123 * *$ & & & & \\
\hline under 14 & $(0.036)$ & $(0.116)$ & $(0.056)$ & $(0.050)$ & & & & \\
\hline Population & $0.340 * *$ & $0.289 *$ & $0.422 * *$ & $0.283 * *$ & & & & \\
\hline over 65 & $(0.035)$ & $(0.140)$ & $(0.083)$ & $(0.079)$ & & & & \\
\hline $\begin{array}{l}\text { Capital acct. } \\
\text { openness }\end{array}$ & $\begin{array}{l}0.127 * * \\
(0.013)\end{array}$ & $\begin{array}{l}0.112 \\
(0.069)\end{array}$ & $\begin{array}{l}0.042 * * \\
(0.015)\end{array}$ & $\begin{array}{l}0.059 * * \\
(0.014)\end{array}$ & $\begin{array}{l}0.040 \\
(0.037)\end{array}$ & $\begin{array}{l}0.058 \\
(0.209)\end{array}$ & $\begin{array}{l}0.050 \\
(0.033)\end{array}$ & $\begin{array}{l}0.048 * * \\
(0.032)\end{array}$ \\
\hline Government & 0.000 & $0.000 *$ & 0.000 & 0.000 & & & & \\
\hline deficit & $(0.000)$ & $(0.000)$ & $(0.000)$ & $(0.000)$ & & & & \\
\hline M2/GDP & $\begin{array}{l}0.360 * * \\
(0.028)\end{array}$ & $\begin{array}{l}0.615^{* *} \\
(0.143)\end{array}$ & $\begin{array}{l}0.244 * * \\
(0.036)\end{array}$ & $\begin{array}{l}0.246 * * \\
(0.038)\end{array}$ & & & & \\
\hline Corruption & & & & & $\begin{array}{l}0.214 * * \\
(0.042)\end{array}$ & $\begin{array}{l}0.273 \\
(0.202)\end{array}$ & $\begin{array}{l}0.107 * * \\
(0.029)\end{array}$ & $\begin{array}{l}0.131 * * \\
(0.031)\end{array}$ \\
\hline $\begin{array}{l}\text { Interaction } \\
\text { term }\end{array}$ & & & & & $\begin{array}{l}0.174 * * \\
(0.047)\end{array}$ & $\begin{array}{l}0.275^{\#} \\
(0.261)\end{array}$ & $\begin{array}{l}0.007 \\
(0.046)\end{array}$ & $\begin{array}{l}0.025 \\
(0.043)\end{array}$ \\
\hline Constant & $\begin{array}{l}-.995^{* *} \\
(0.070)\end{array}$ & $\begin{array}{l}-1.234^{* *} \\
(0.241)\end{array}$ & & $\begin{array}{l}-.654 * * \\
(0.120)\end{array}$ & $\begin{array}{l}-.419 * * \\
(0.040)\end{array}$ & $\begin{array}{l}-.553^{* *} \\
(0.189)\end{array}$ & & $\begin{array}{l}-.334 * * \\
(0.057)\end{array}$ \\
\hline Adjusted $\mathrm{R}^{2}$ & 0.520 & 0.604 & 0.790 & 0.509 & 0.517 & 0.605 & 0.834 & 0.505 \\
\hline $\begin{array}{l}\text { F-test } \\
\text { statistic }\end{array}$ & & & $26.697 * *$ & & & & $37.878^{* *}$ & \\
\hline $\begin{array}{l}\text { Hausman } \\
\text { test statistic }\end{array}$ & & & & $15.561 * *$ & & & & $18.213^{* *}$ \\
\hline $\begin{array}{l}\text { Number of } \\
\text { observation } \\
\text { s }\end{array}$ & 2626 & & & & 2111 & & & \\
\hline
\end{tabular}

Notes: Under the heading "demographics, policy, and financial development" the sample covers 132 countries with data available between 1975 and 2004. Under the heading "capital account openness and corruption," the sample covers 111 countries with data available between 1975 and 2004. The panel is unbalanced due to some missing observations. ${ }^{*}$ and $*$ indicate $1 \%$ and $5 \%$ levels of significance, respectively. Heteroskedasticity-robust standard errors are given in parentheses underneath coefficient estimates. For the fixed effects models, the F-test statistics are reported for the null hypothesis of the equality of the constants across all countries in the sample. For the random effects models, the Hausman test statistics test for the independence between the time-invariant country-specific effects and the regressors. 
Table 7: Estimation with control variables and a current account balance variable

\begin{tabular}{|c|c|c|c|c|c|c|c|c|}
\hline & \multicolumn{4}{|c|}{$\begin{array}{l}\text { Demographics, policy, and financial } \\
\text { development }\end{array}$} & \multicolumn{4}{|c|}{ Capital account openness and corruption } \\
\hline & $\begin{array}{l}\text { Pooled } \\
\text { OLS }\end{array}$ & Between & $\begin{array}{l}\text { Fixed } \\
\text { effects } \\
\text { (Within) }\end{array}$ & $\begin{array}{l}\text { Random } \\
\text { effects }\end{array}$ & $\begin{array}{l}\text { Pooled } \\
\text { OLS }\end{array}$ & $\begin{array}{l}\text { Betwee } \\
\mathrm{n}\end{array}$ & $\begin{array}{l}\text { Fixed } \\
\text { effects } \\
\text { (Within) }\end{array}$ & $\begin{array}{l}\text { Random } \\
\text { effects }\end{array}$ \\
\hline GDP per & $0.258 * *$ & $0.246^{* *}$ & $0.270 * *$ & $0.275 * *$ & $0.245 * *$ & $0.215 * *$ & $0.076^{\#}$ & $0.240 * *$ \\
\hline $\begin{array}{l}\text { capita } \\
\text { Popuation }\end{array}$ & $\begin{array}{l}(0.014) \\
0.387 * *\end{array}$ & $\begin{array}{l}(0.048) \\
0.412 * *\end{array}$ & $\begin{array}{l}(0.039) \\
0.166^{* *}\end{array}$ & $\begin{array}{l}(0.024) \\
0.227^{* *}\end{array}$ & & & & \\
\hline under 14 & $(0.041)$ & $(0.117)$ & $(0.060)$ & $(0.054)$ & & & & \\
\hline $\begin{array}{l}\text { Population } \\
\text { over } 65\end{array}$ & $\begin{array}{l}0.364 * * \\
(0.040)\end{array}$ & $\begin{array}{l}0.314^{*} \\
(0.146)\end{array}$ & $\begin{array}{l}0.275^{* *} \\
(0.104)\end{array}$ & $\begin{array}{l}0.234 * * \\
(0.087)\end{array}$ & & & & \\
\hline $\begin{array}{l}\text { Capital } \\
\text { acct. } \\
\text { openness }\end{array}$ & $\begin{array}{l}0.147 * * \\
(0.014)\end{array}$ & $\begin{array}{l}0.096 \\
(0.068)\end{array}$ & $\begin{array}{l}0.106^{* *} \\
(0.016)\end{array}$ & $\begin{array}{l}0.114 * * \\
(0.016)\end{array}$ & $\begin{array}{l}-0.014 \\
(0.039)\end{array}$ & $\begin{array}{l}0.042 \\
(0.218)\end{array}$ & $\begin{array}{l}0.037 \\
(0.034)\end{array}$ & $\begin{array}{l}0.034 \\
(0.033)\end{array}$ \\
\hline $\begin{array}{l}\text { Governmen } \\
\mathrm{t} \\
\text { deficit }\end{array}$ & $\begin{array}{l}0.000 \\
(0.000)\end{array}$ & $\begin{array}{l}0.000^{*} \\
(0.000)\end{array}$ & $\begin{array}{l}0.000 \\
(0.000)\end{array}$ & $\begin{array}{l}0.000 \\
(0.000)\end{array}$ & & & & \\
\hline M2/GDP & $\begin{array}{l}0.379 * * \\
(0.034)\end{array}$ & $\begin{array}{l}0.570^{* *} \\
(0.158)\end{array}$ & $\begin{array}{l}0.200 * * \\
(0.045)\end{array}$ & $\begin{array}{l}0.231^{* *} \\
(0.045)\end{array}$ & & & & \\
\hline Corruption & & & & & $\begin{array}{l}0.239 * * \\
(0.042)\end{array}$ & $\begin{array}{l}0.300 \\
(0.203)\end{array}$ & $\begin{array}{l}0.057^{\#} \\
(0.030)\end{array}$ & $\begin{array}{l}0.102 * * \\
(0.032)\end{array}$ \\
\hline $\begin{array}{l}\text { Interaction } \\
\text { term }\end{array}$ & & & & & $\begin{array}{l}0.227 * * \\
(0.048)\end{array}$ & $\begin{array}{l}0.264 \\
(0.268)\end{array}$ & $\begin{array}{l}0.039 \\
(0.047)\end{array}$ & $\begin{array}{l}0.060 \\
(0.043)\end{array}$ \\
\hline $\begin{array}{l}\text { Lagged } \\
\text { current acct. }\end{array}$ & $\begin{array}{l}0.003^{* *} \\
(0.001)\end{array}$ & $\begin{array}{l}0.003 \\
(0.005)\end{array}$ & $\begin{array}{l}-0.003 * * \\
(0.001)\end{array}$ & $\begin{array}{l}-0.002 * * \\
(0.000)\end{array}$ & $\begin{array}{l}0.001 \\
(0.001)\end{array}$ & $\begin{array}{l}0.001 \\
(0.005)\end{array}$ & $\begin{array}{l}-0.004 * * \\
(0.001)\end{array}$ & $\begin{array}{l}-0.003 * * \\
(0.000)\end{array}$ \\
\hline Constant & $\begin{array}{l}-1.139 * * \\
(0.087)\end{array}$ & $\begin{array}{l}-1.262 * * \\
(0.252)\end{array}$ & & $\begin{array}{l}-0.768^{* * *} \\
(0.132)\end{array}$ & $\begin{array}{l}-0.449 * * \\
(0.041)\end{array}$ & $\begin{array}{l}-0.569 * * \\
(0.197)\end{array}$ & & $\begin{array}{l}-0.360^{* * *} \\
(0.058)\end{array}$ \\
\hline Adjusted $\mathrm{R}^{2}$ & 0.512 & 0.579 & 0.782 & 0.497 & 0.514 & 0.582 & 0.836 & 0.498 \\
\hline $\begin{array}{l}\text { F-test } \\
\text { statistic }\end{array}$ & & & $23.232 * *$ & & & & $36.907 * *$ & \\
\hline $\begin{array}{l}\text { Hausman } \\
\text { test statistic }\end{array}$ & & & & $11.596^{*}$ & & & & $114.62 * *$ \\
\hline $\begin{array}{l}\text { Number of } \\
\text { observation } \\
s\end{array}$ & 2244 & & & & 1987 & & & \\
\hline
\end{tabular}

Notes: Under the heading "demographics, policy, and financial development" the sample covers 132 countries with data available between 1975 and 2004. Under the heading "capital account openness and corruption," the sample covers 111 countries with data available between 1975 and 2004. The panel is unbalanced due to some missing observations. **, *, and \# indicate 1\%, 5\%, and $10 \%$ levels of significance, respectively. Heteroskedasticity-robust standard errors are given in parentheses underneath coefficient estimates. For the fixed effects models, the F-test statistics are reported for the null hypothesis of the equality of the constants across all countries in the sample. For the random effects models, the Hausman test statistics test for the independence between the time-invariant country-specific effects and the regressors. The "Lagged current acct." is the current account to GDP ratio lagged by one period. 


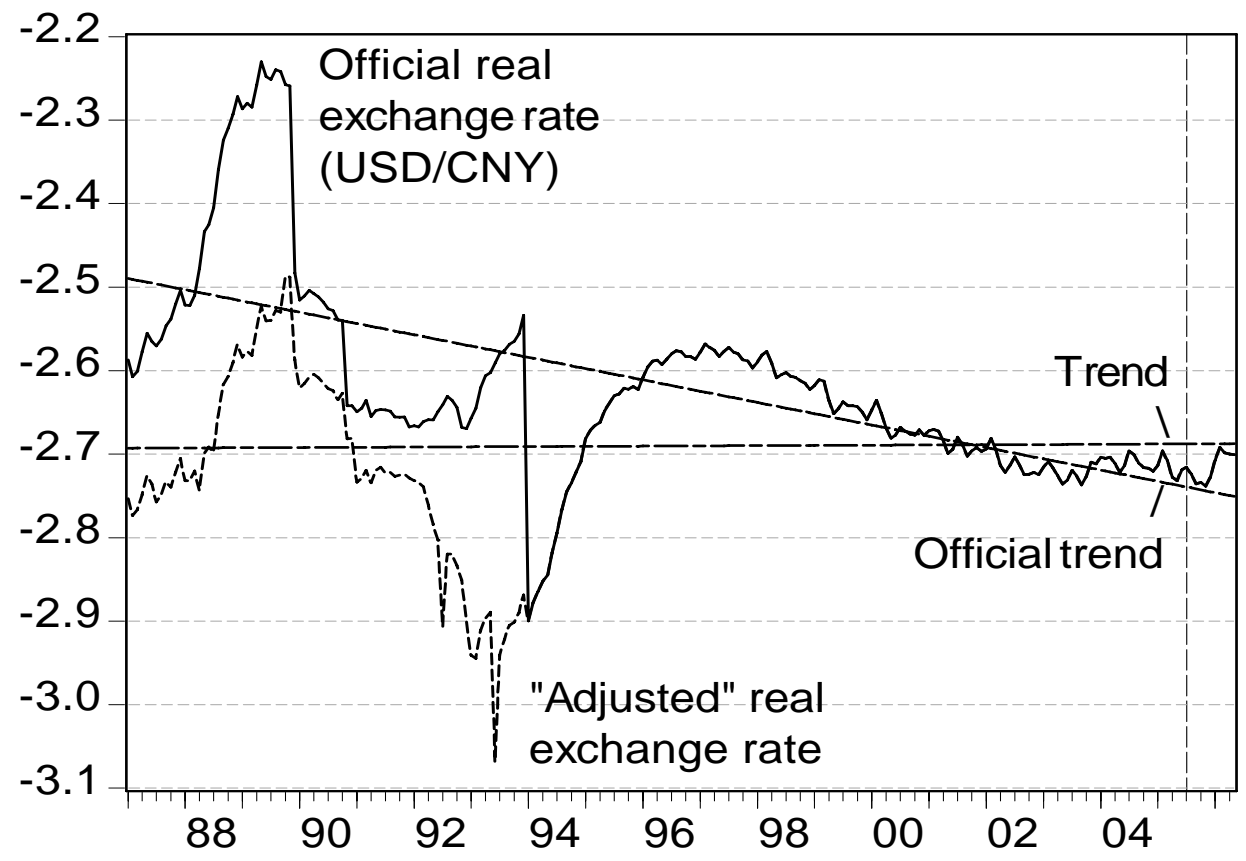

Figure 1: Real Chinese exchange rate, in logs (Official and "Adjusted") and trends

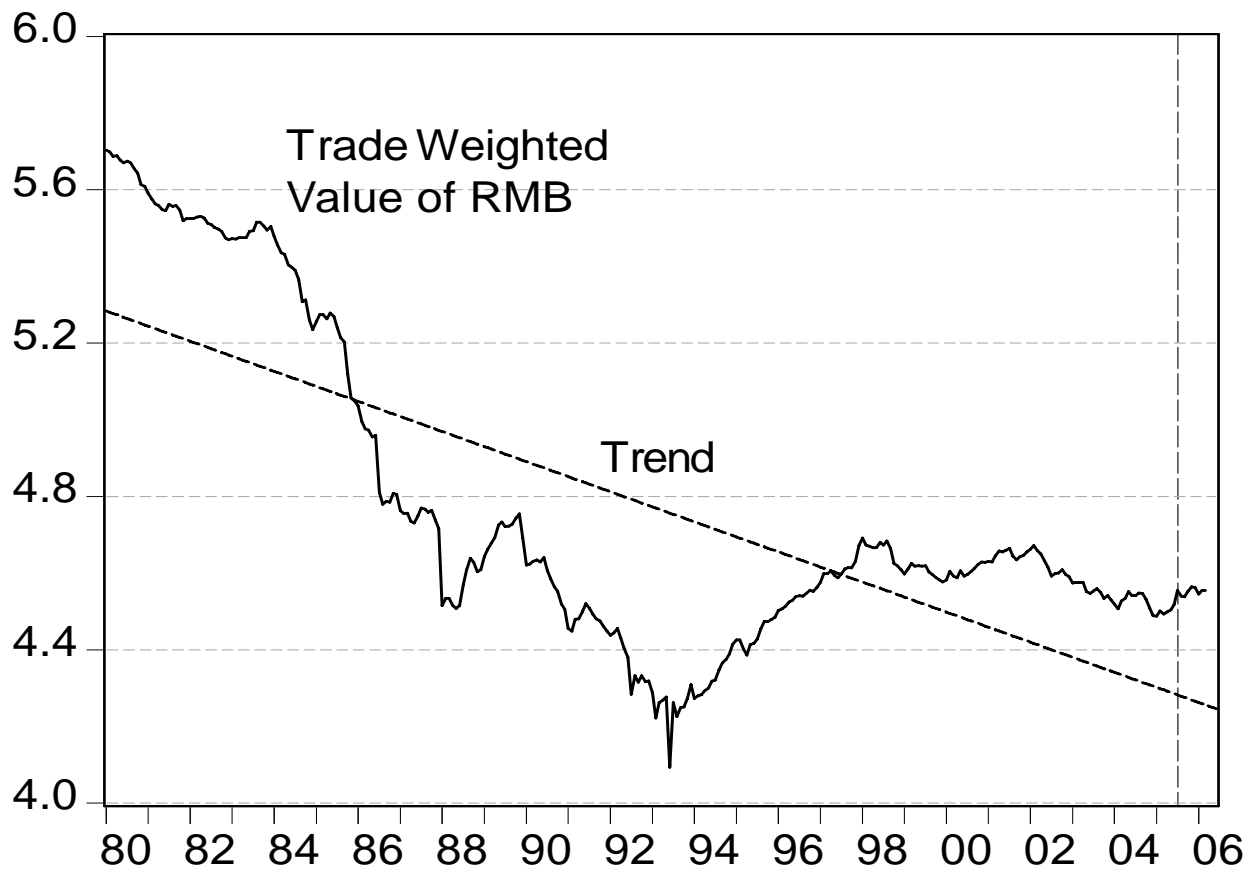

Figure 2: Real trade weighted value of RMB, in logs, and trend. 
Relative price level

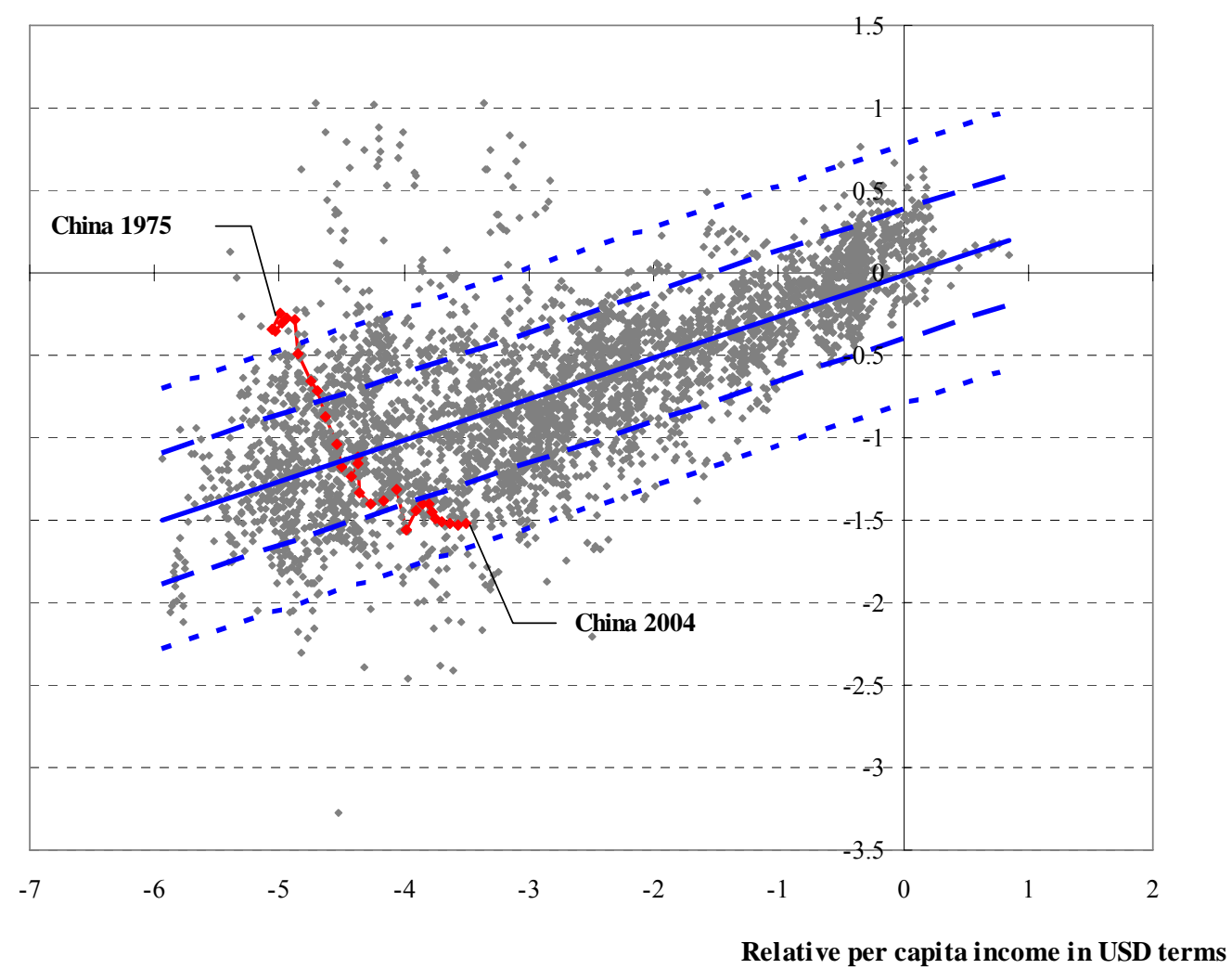

Figure 3: The rate of RMB misalignment based on the pooled OLS estimates with the USDbased per capita income 


\section{Relative price level}

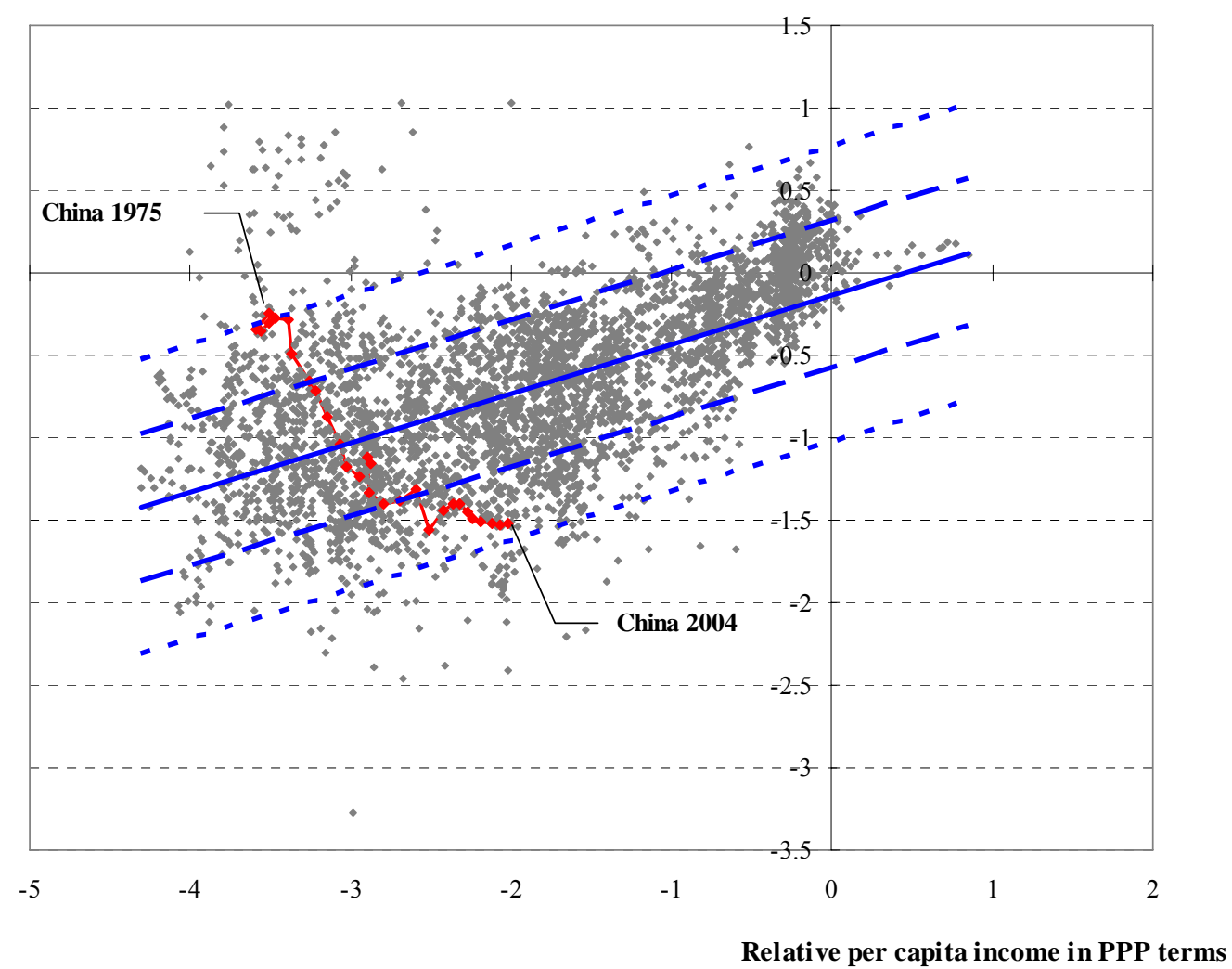

Figure 4: The rate of RMB misalignment based on the pooled OLS estimates with the PPPbased per capita income 


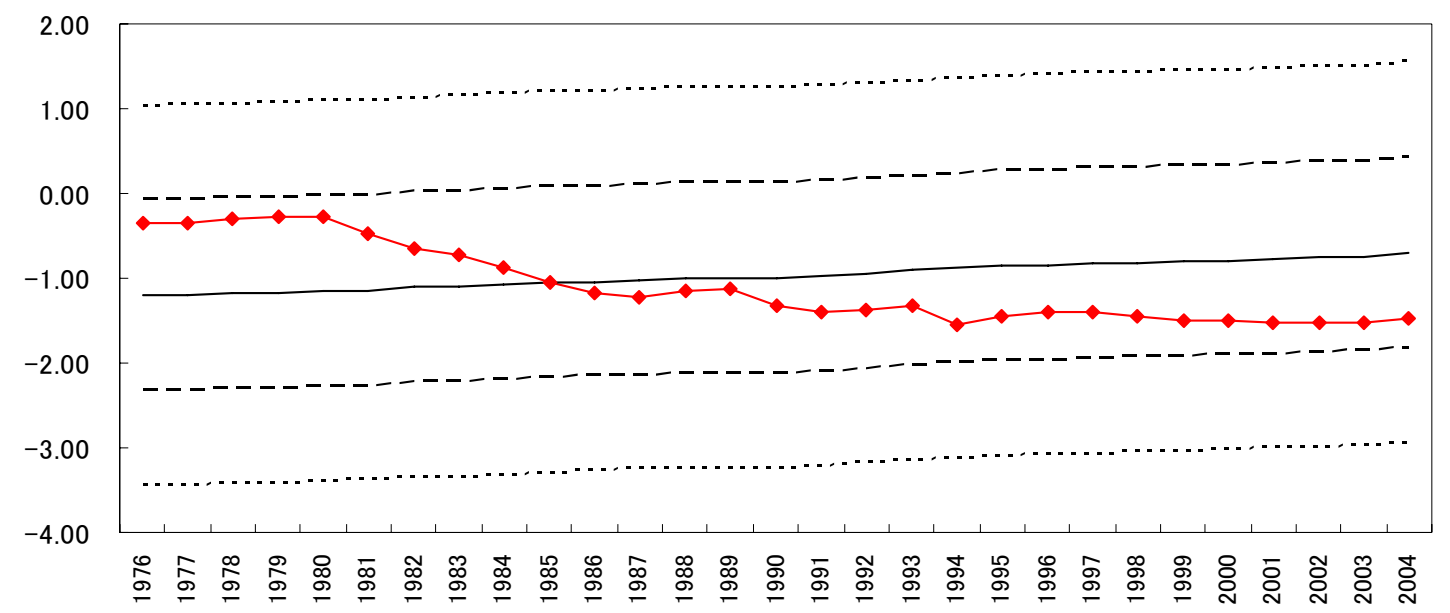

$\longrightarrow$ Actual $\longrightarrow$ Predicted $\cdots \cdots+2$ std. ----+1 std. -----1 std. $\cdots \cdots+-2$ std.

Figure 5: PPP-based real income, pooled OLS estimates with ad-hoc AR1 adjustment

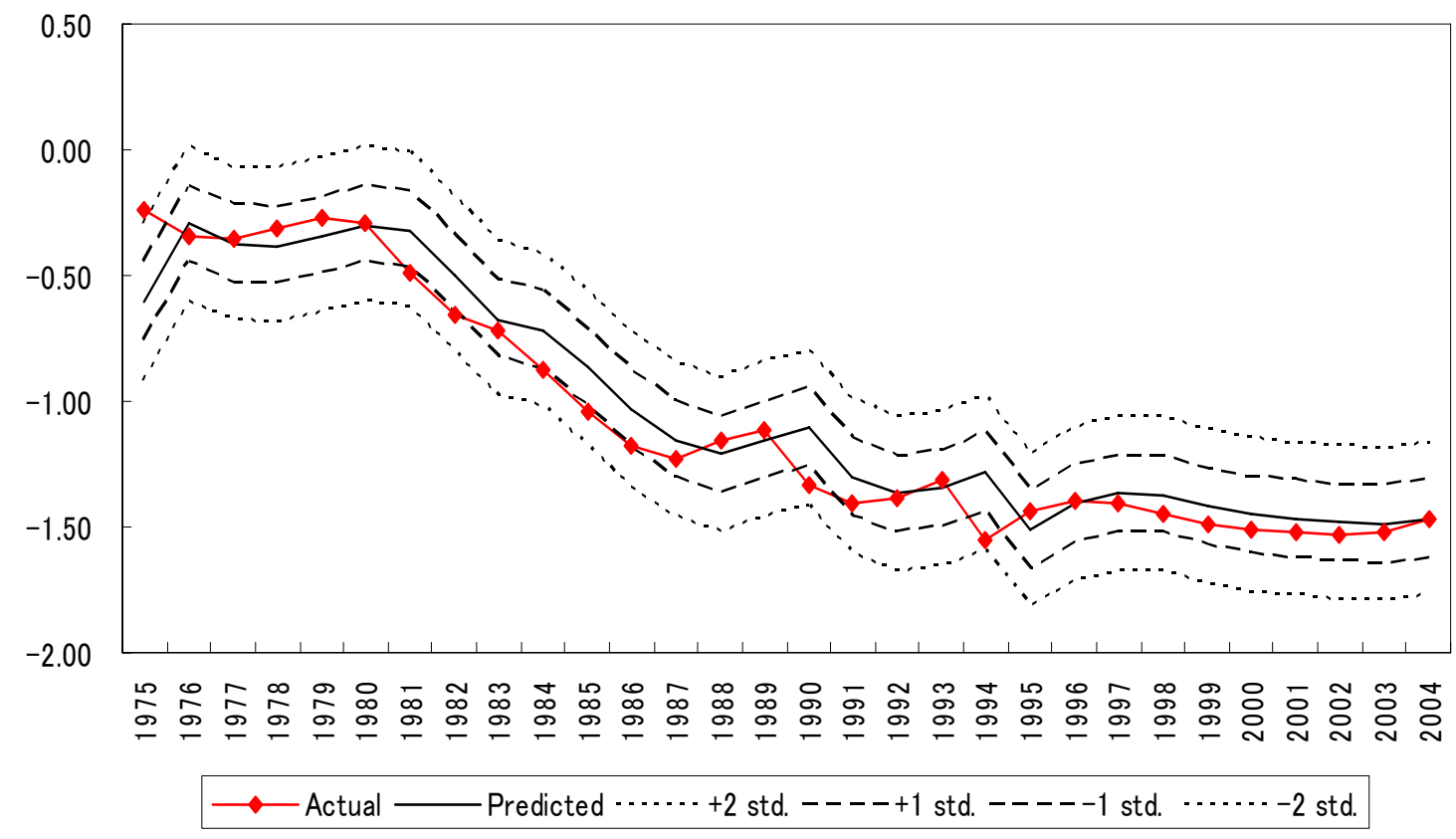

Figure 6: PPP-based real income, the Prais-Winsten estimates 


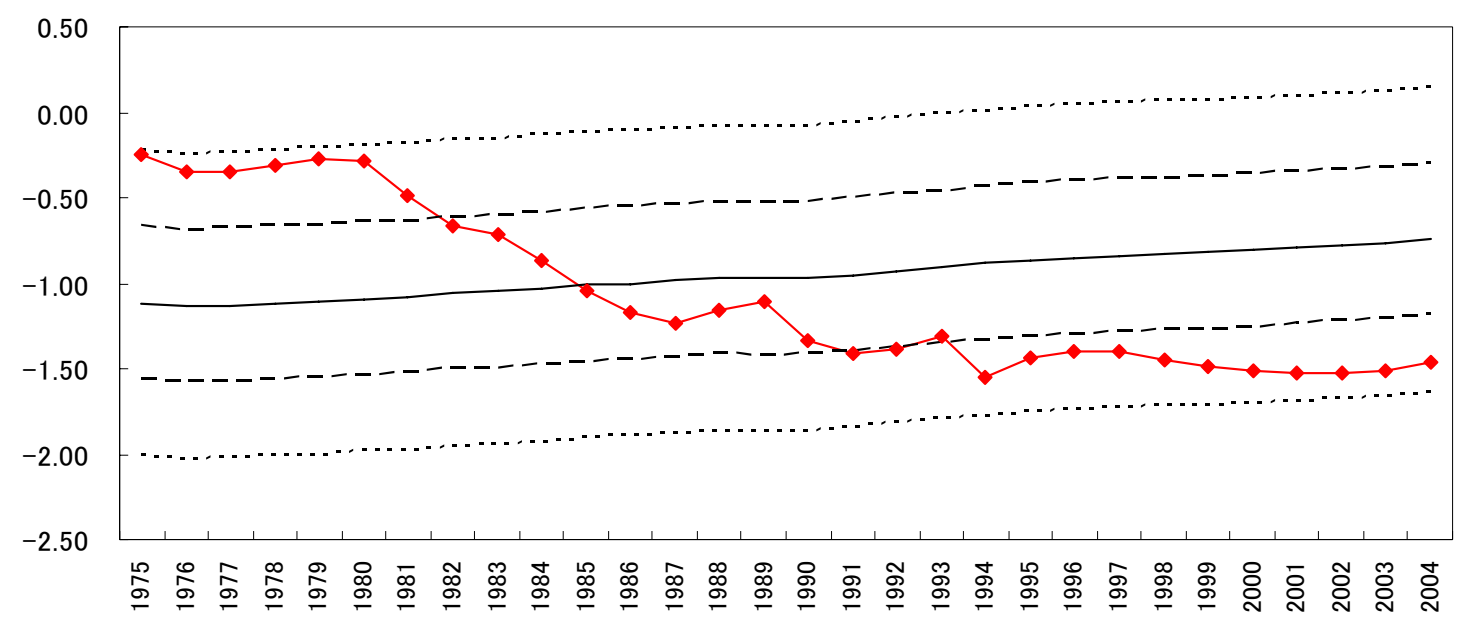

$\longrightarrow$ Actual $\longrightarrow$ Predicted $\cdots+\cdots+2$ std. ----+1 std. -----1 std. $\cdots+\cdots-2$ std.

Figure 7: PPP-based real income, pooled OLS estimates with the less developed country sample

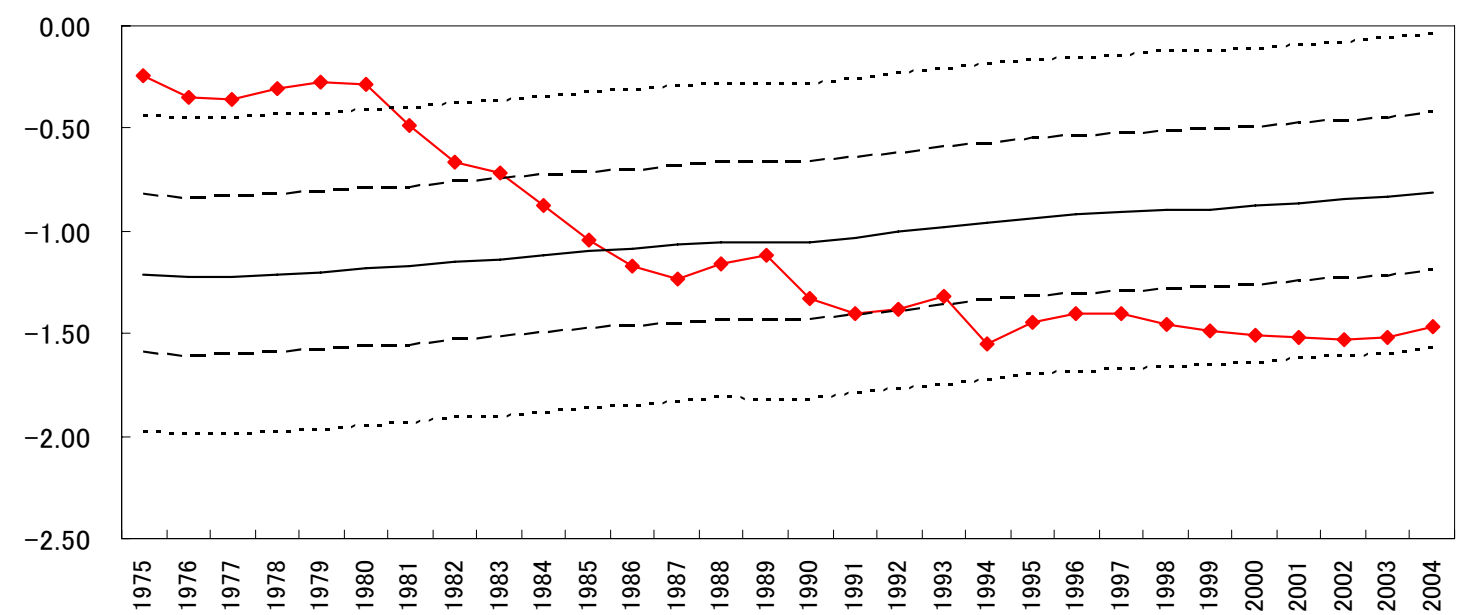

$\longrightarrow$ Actual $\longrightarrow$ Predicted $\cdots+\cdots+2$ std. ----+1 std. -----1 std. $\cdots+\cdots-2$ std.

Figure 8: PPP-based real income, pooled OLS estimates with the middle income country sample 


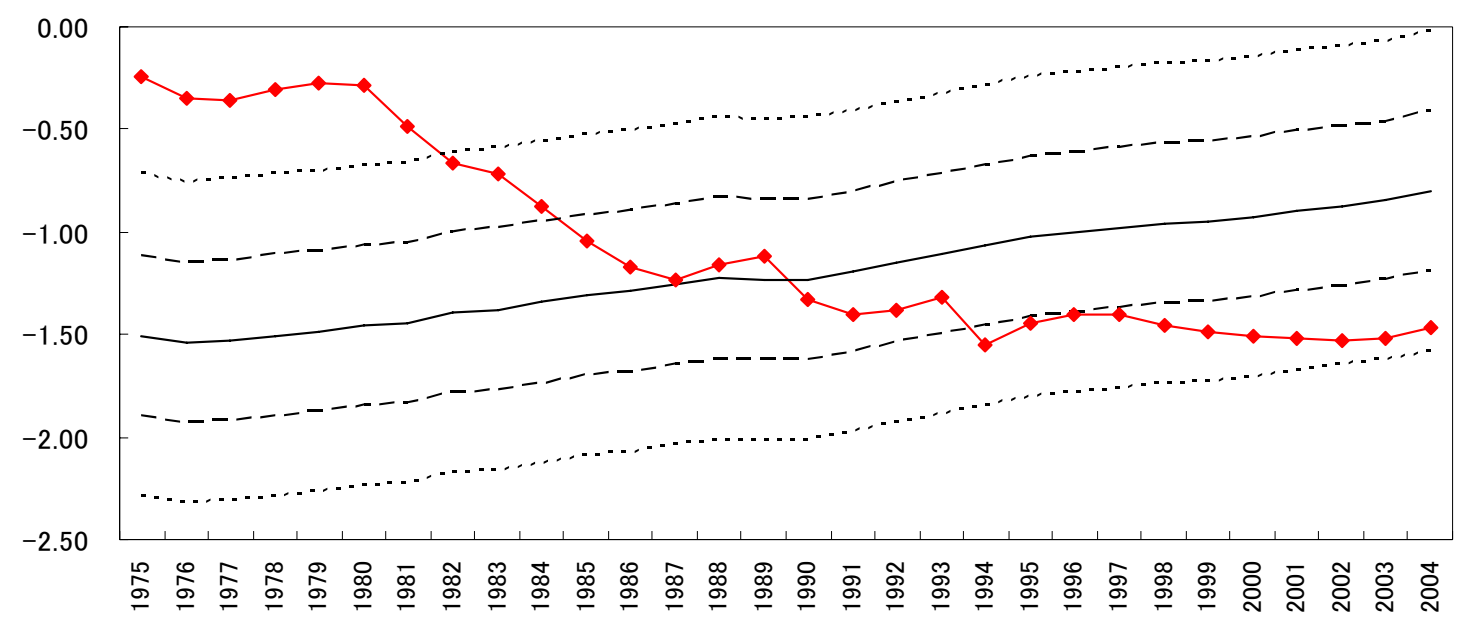

$\longrightarrow$ Actual $\longrightarrow$ Predicted $\cdots+\cdots+2$ std. ----+1 std. -----1 std. $\cdots+\cdots-2$ std.

Figure 9: PPP-based real income, pooled OLS estimates with the East Asian country sample

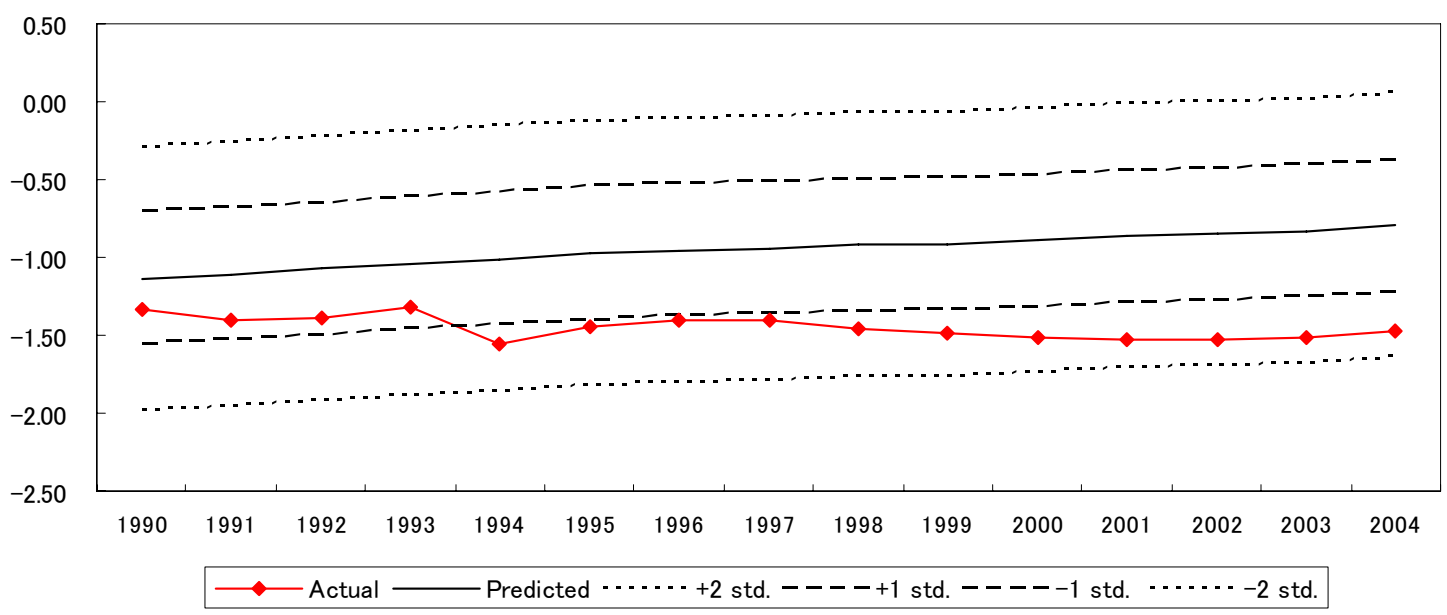

Figure 10: PPP-based real income, pooled OLS estimates with the 1990-2004 sample 


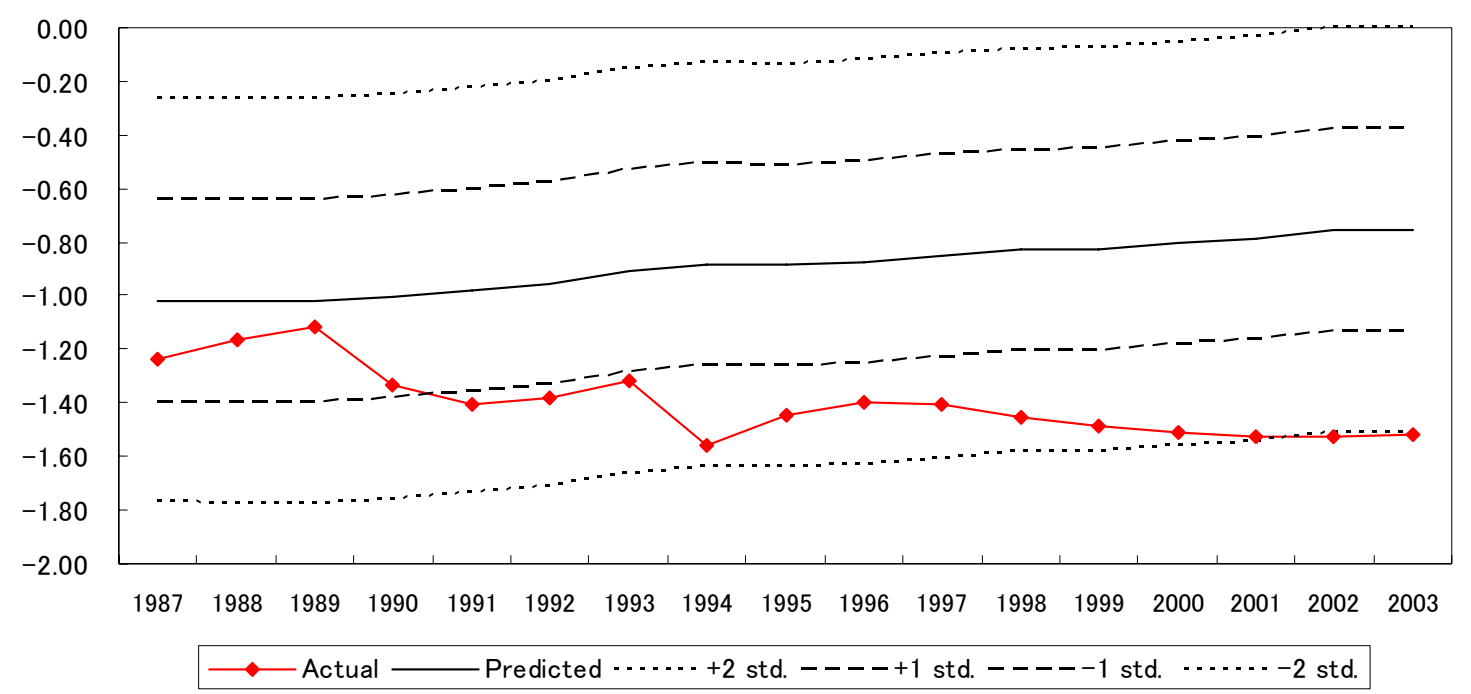

Figure 11: PPP-based real income, pooled OLS estimates with the demographics, policy and financial development as controls

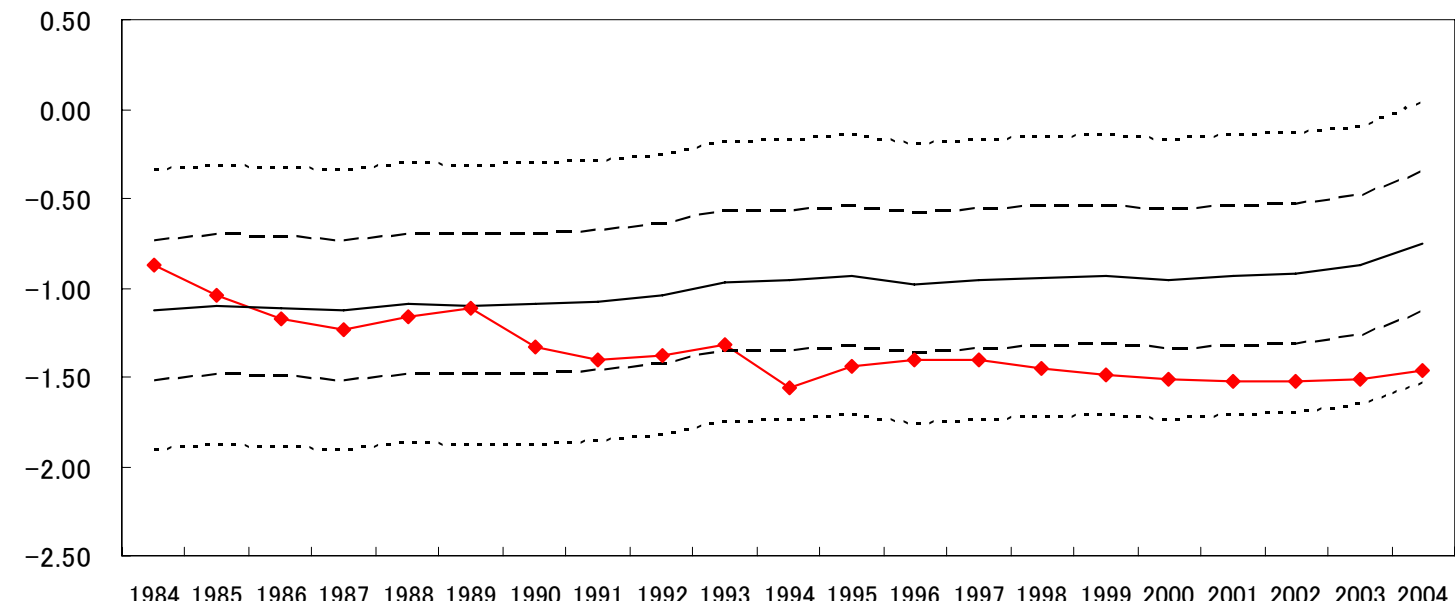

$$
\longrightarrow \text { Actual } \longrightarrow \text { Predicted } \cdots \cdots+2 \text { std. }----+1 \text { std. }-----1 \text { std. } \cdots \cdots-2 \text { std. }
$$

Figure 12: PPP-based real income, pooled OLS estimates with the capital account openness and institutions as controls 


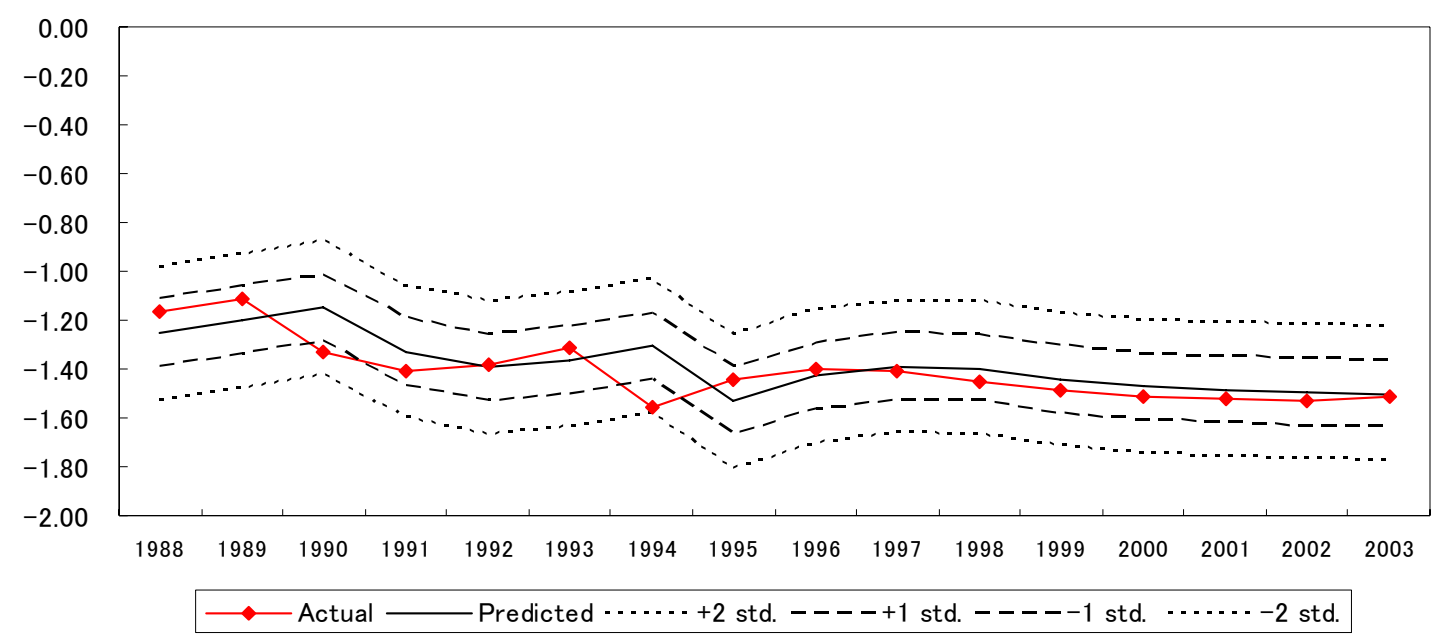

Figure 13: PPP-based real income, pooled OLS estimates with the demographics, policy and financial development as controls, Prais-Winsten estimates

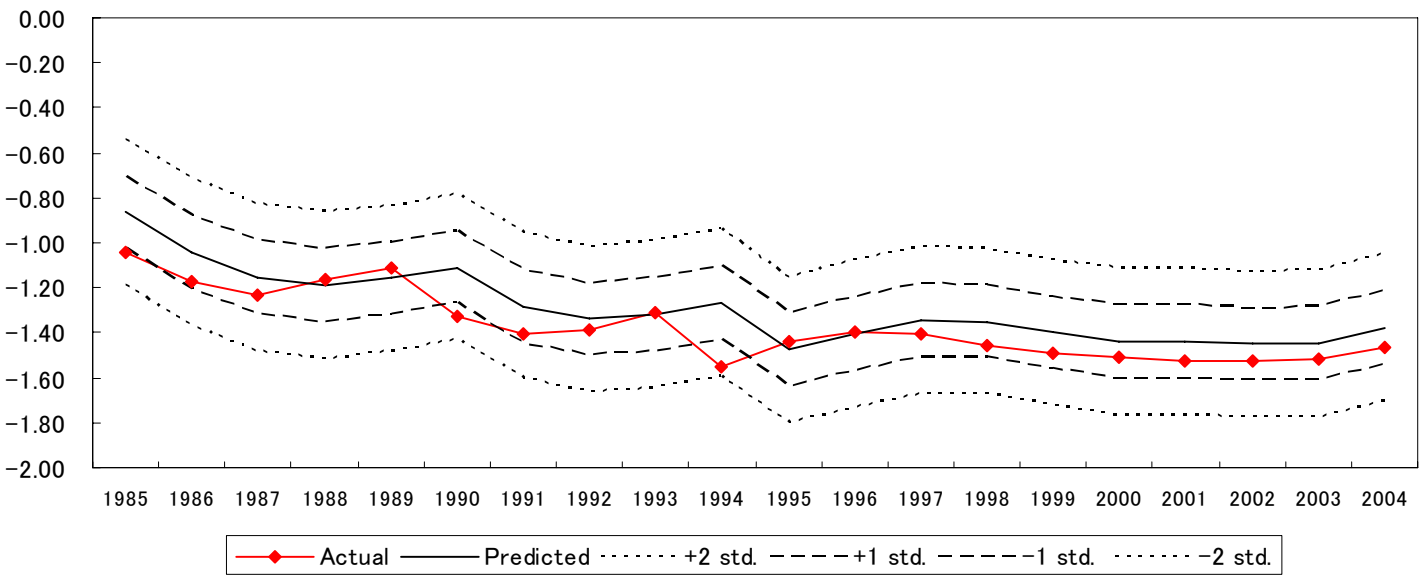

Figure 14: PPP-based real income, pooled OLS estimates with the capital account openness and institutions as controls, Prais-Winsten estimates 


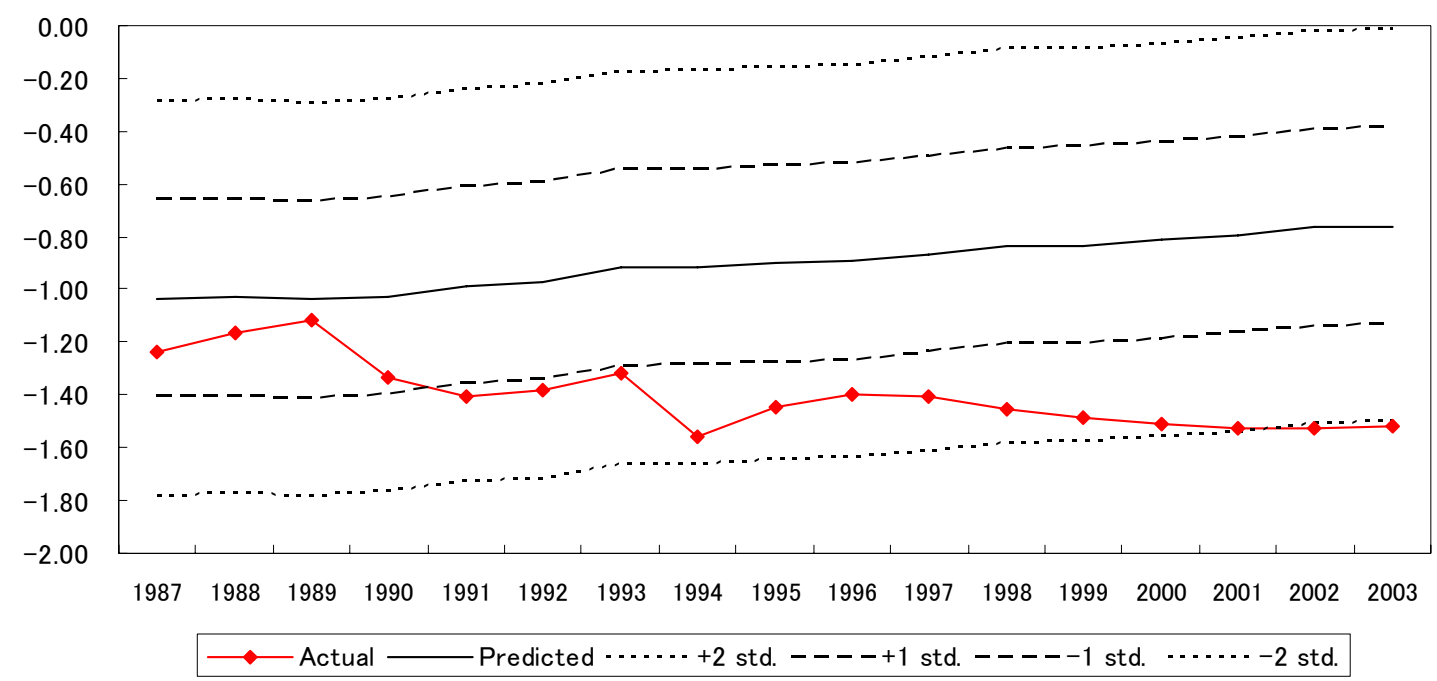

Figure 15: The actual and predicted RMB values by pooled OLS estimates with the demographics, policy, financial development, and lagged current account as controls

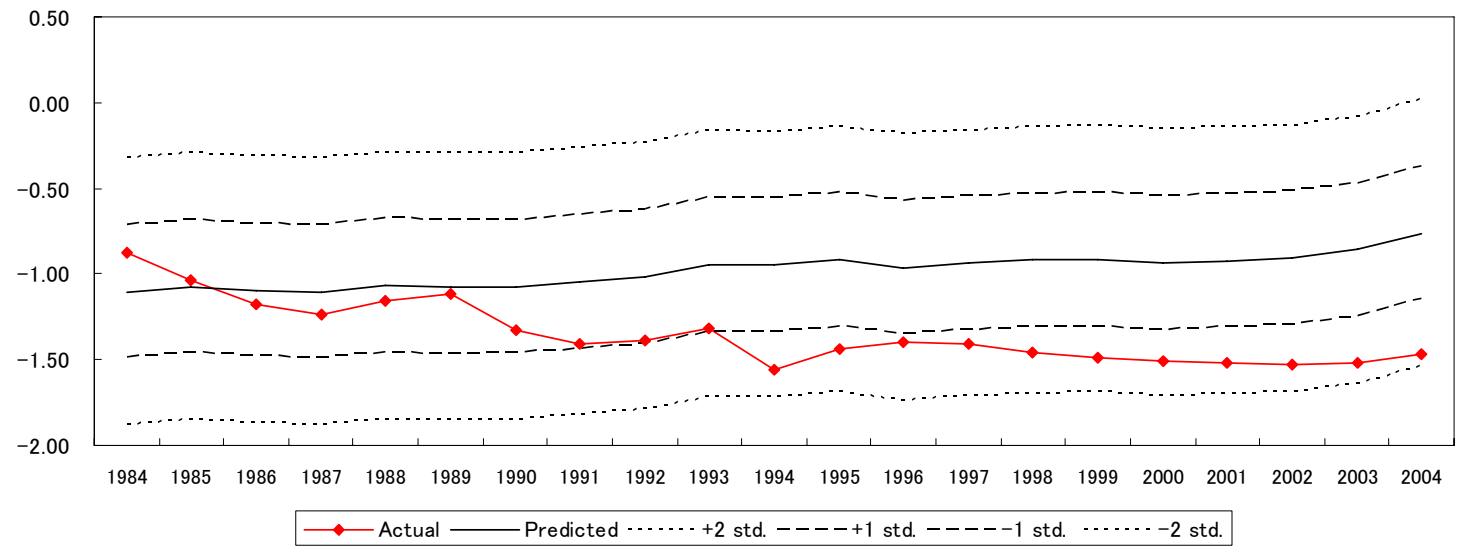

Figure16: The actual and predicted RMB values by pooled OLS estimates with the capital account openness, institutions, and lagged current account as controls 